Historic, Archive Document

Do not assume content reflects current scientific knowledge, policies, or practices. 



\section{CHRYSANTHEMUMS AND OTHER PLANTS FOR 1910}

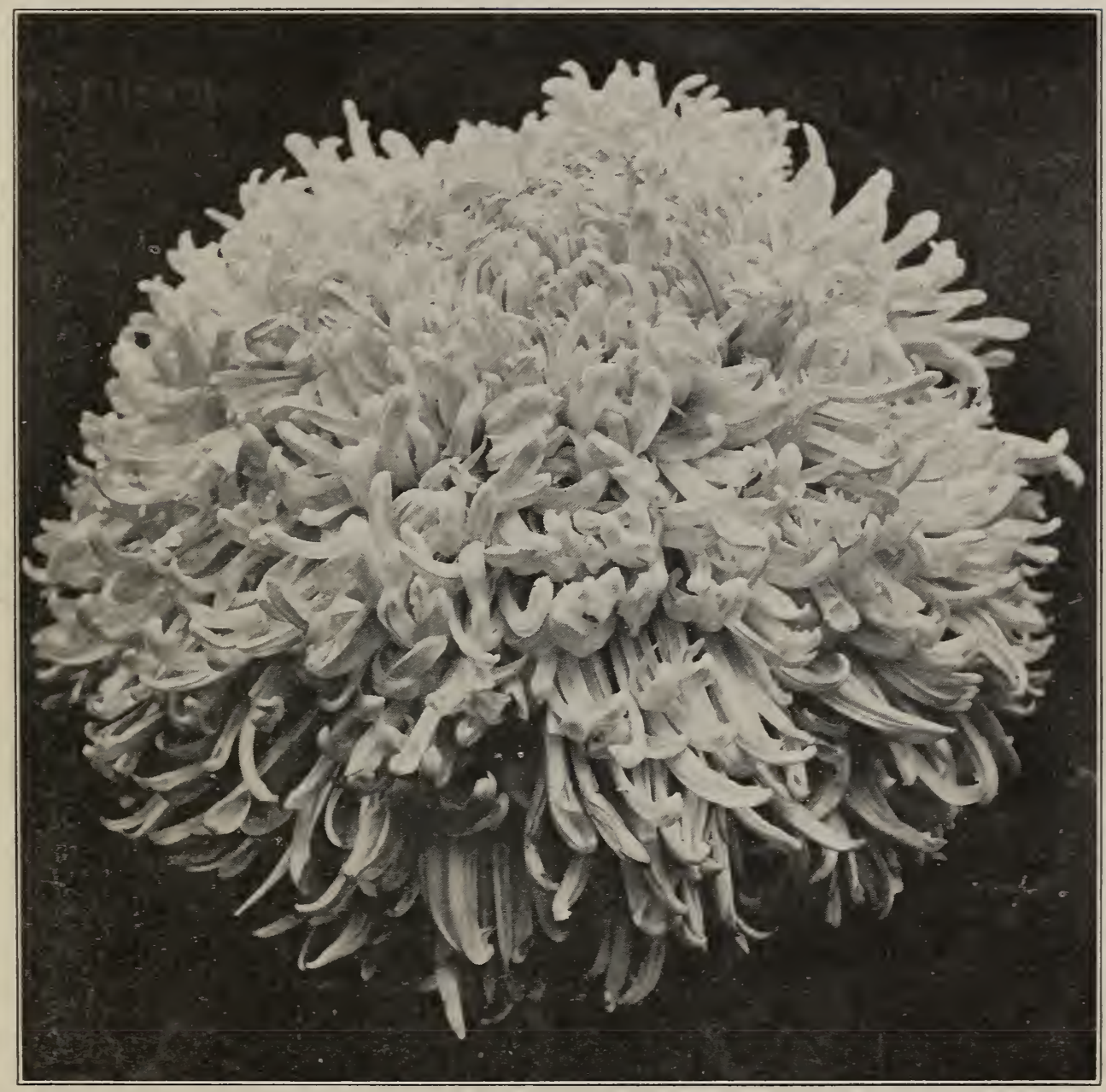

Onunda

\section{CHARLES H. TOTTY}

MADISON,

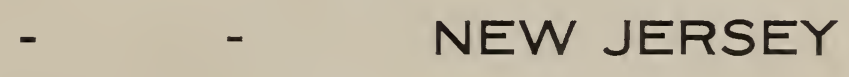





\section{Preface}

EXTEND my sincere thanks to my customers for their kind support during the past year and I know that the varieties of this year's introduction will be found well worthy of your commendation. Last year's varieties have been called the best I ever sent out but it will be found that this year we will do just a little better. I am very pleased to announce that having made an agreement with W. Wells of England, regarding the dissemination of the Wells-Pockett varieties, I am this year, for the first time, offering to American exhibition growers the same list of varieties that is being sent out in England. We have previously always been a year behind, but this arrangement enables the American exhibitor to get his varieties at the same time as the European exhibitor and having been grown here there is no vexatious customs delivery, which is the cause of the loss of practically two-thirds of varieties imported.

I have not exhibited for prizes this year, but the flowers that I have exhibited at the different shows, "Not for Competition," have called forth the warmest approval and 1910 will set a still higher standard for chrysanthemum culture.

CHARLES H. TOTTY. 


\section{The Special Wells-Pockett Set for 1910.}

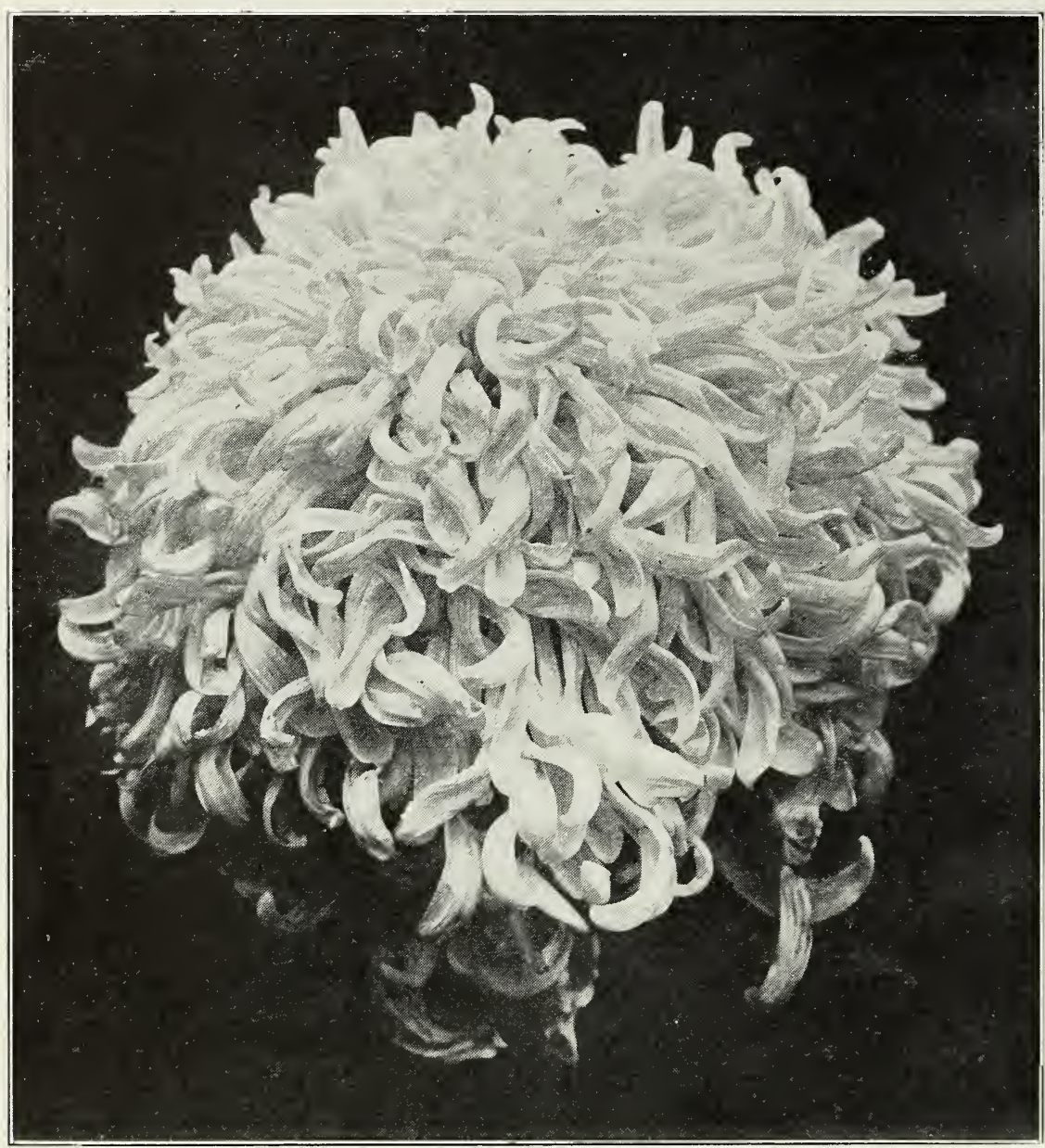

MRS. DAVID SYME.

\section{Mrs. David Syme.}

A grand white that is booked to displace all of our other whites on the exhibition table. It is as large as Moir, when the latter is well done. It carries the foliage right up to the flower, stem absolutely perfect, and when taken on the bud about August 15th, produces a flower that is as near perfection in its color as it is possible to get. Mrs. David Syme has been certificated in England, has won the gold medal in Australia, and would have scored very high in this country had I sufficient stock to place it before any committee. Price $\$ 2.00$ per plant, $\$ 20.00$ per dozen. 


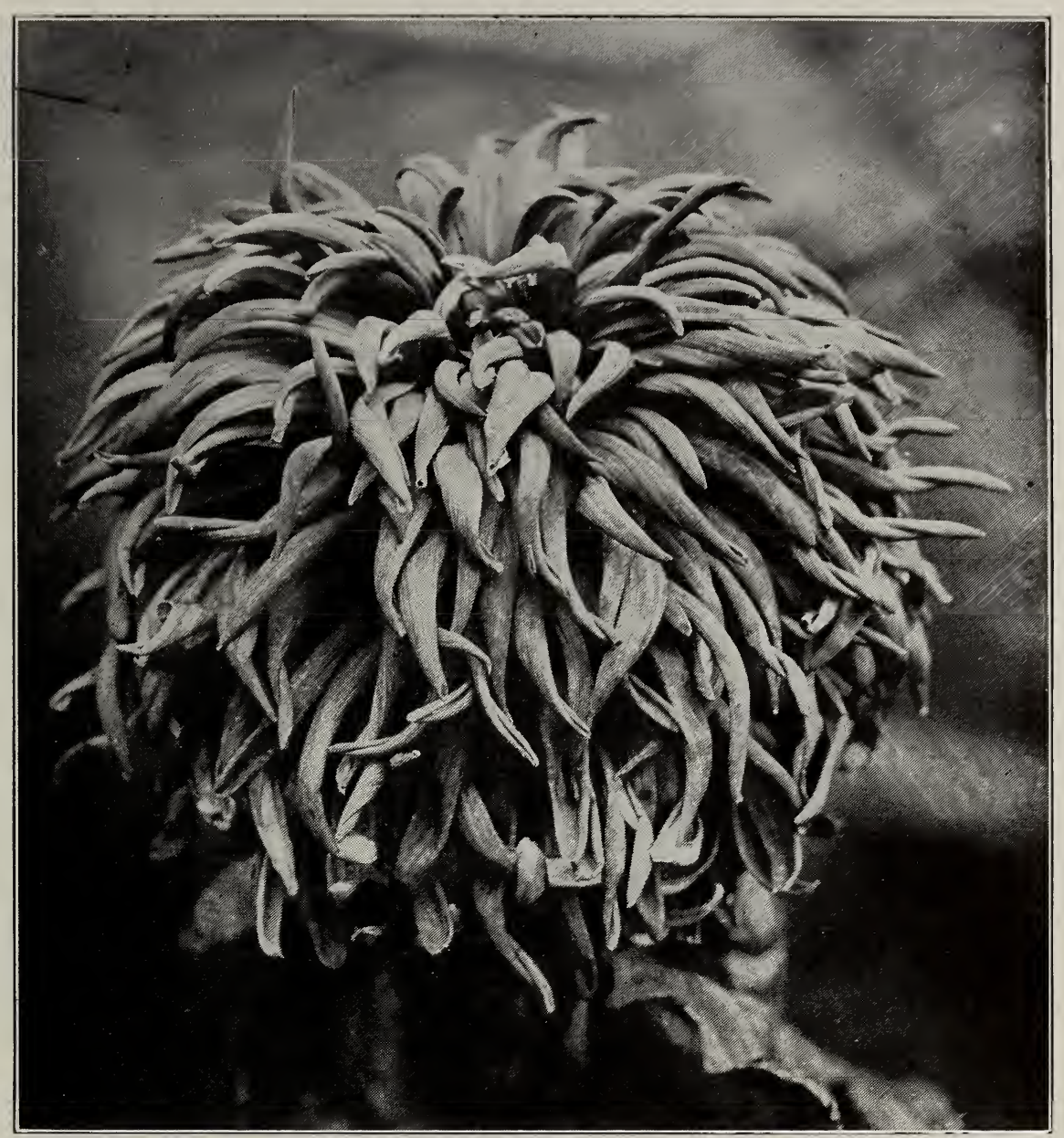

MRS. W. A. READ

Mrs. W. A. Read.

An intense, fiery, scarlet crimson, petals standing out stiff to show the color to the best advantage. This variety is perfect in foliage, which is right up to the flower, stiff stem, grows rather above the average height, and will undoubtedly make its mark in the crimson classes as a striking exhibition variety. Any bud after August 15 th produces a perfect flower. Price $\$ 2.00$ per plant, $\$ 20.00$ per dozen. 


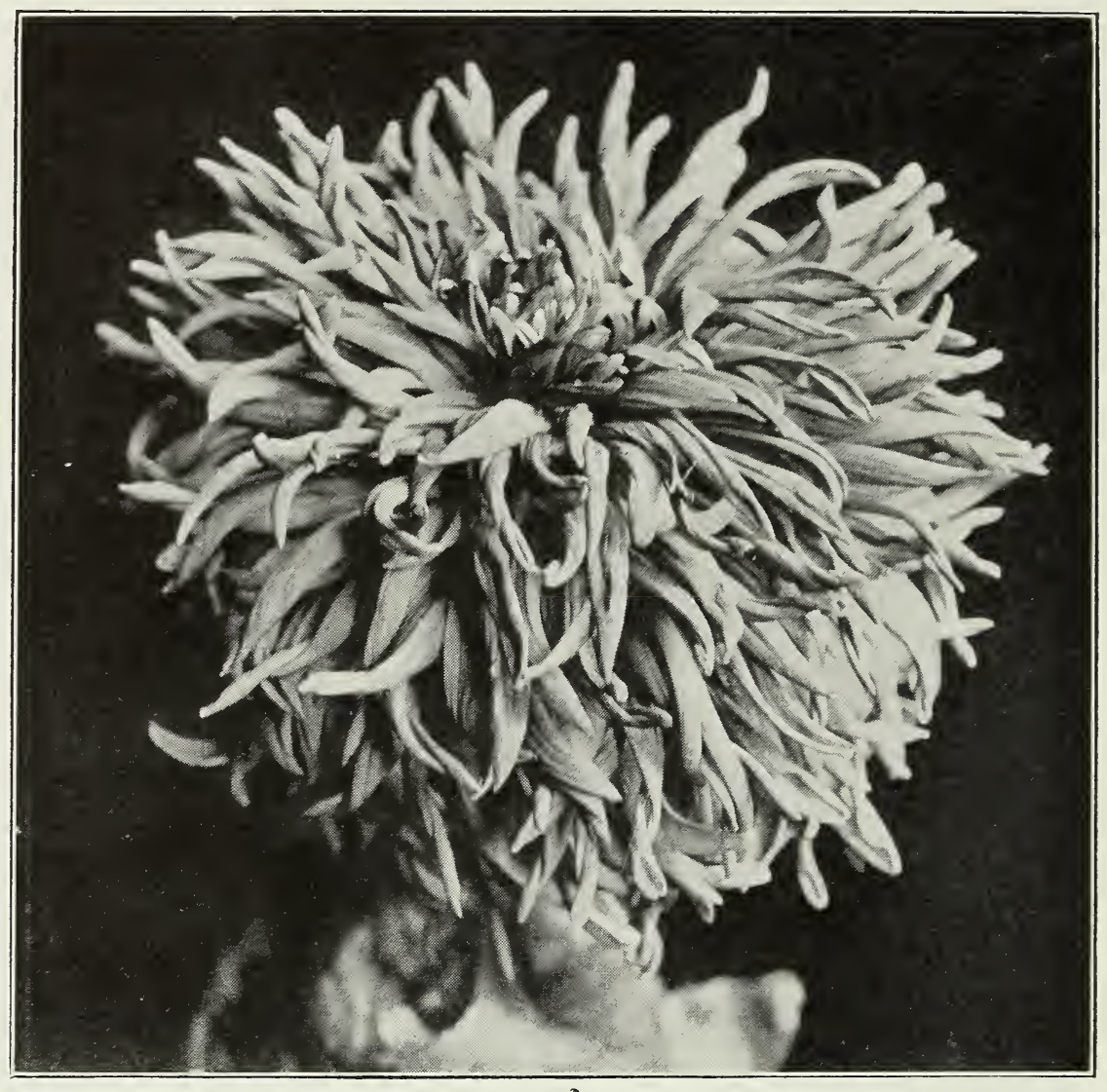

MRS. R. LUXFORD

Mrs. R. Luxford.

Indian red, with a golden reverse, splendid dwarf grower; this variety would make an ideal pot plant. As grown with us, it does not come large enough to be used for exhibition, but buds taken early in August produce very fine flowers for cut blooms, ahead of any other red that we now have. This variety should rank high as an early commercial red. The color blends excellently with autumn foliage when used in decorations.

Price $\$ 2.00$ per plant, $\$ 20.00$ per dozen. 


\section{The Special Wells-Pockett Set for 1910.}

HOWARD GOULD. This will be a splendid variety. The florets are long and grooved and the flower builds up into an enormous globe, splendid in form and substance. The inside of the petals are of a bright golden chestnut, with a reverse of pure deep gold. The general effect of the flower is splendid in the extreme. The stem is stiff, the foliage is very handsome and this variety will rank well up with the best of the Wells-Pockett previous introductions. Price $\$ 2.00$ per plant $\$ 20.00$ per dozen.

MISS ALICE FINCH. A splendid flower of the Brook shade of color, a purple crimson. Unlike Brook's though, every flower reflexes, showing the flower to the best advantage. Habit, perfect; foliage, right up to the flower; stem, stiff and of medium height. Crown bud 20th of August, produced the best results with us this year. This is a color we are short of and every exhibitor should add this variety to his collection.

ROSE ELLIS. Described as an improved Lady Hopetown. It is practically the same color as Hopetown and also has the same defect, a weak neck, which renders it unable to hold the head erect. The color is beautiful and the flower enormous, but it can only be recommended to be grown for the short vase or supported classes.

MISS EDITH KING. An improved Mrs. Knox. Color, bright canary yellow, very broad florets. The outer petals curl and twist round like shavings, has the Wells-Pockett growth, sturdy and robust, and perhaps is the most refined looking flower we have.

KARA DOW. Chestnut with a bronze reverse. This variety is described by Mr. Pockett as the biggest bronze in existence. It is a little necky, but will be found to make a magnificent variety for the short vase classes.

W. WOOD MASON. Mr. Pockett, in naming this variety, says, "my finest crimson." The color is not so intense as Pockett's Crimson, but the flower is very much larger. With a more extended trial, this variety may force itself to the head of the list of crimsons. As a plant is an excellent doer and habits seem all that can be desired.

ALICE LEMON. A beautiful flower of light soft pink, stem and foliage fine, the flower is very large, but not coarse in any degree and this variety. will probably be shown much better another year.

Prices on all these varieties $\$ 2.00$ per plant, $\$ 20.00$ per dozen. 


\section{Onunda}

\section{A Great American Seedling.}

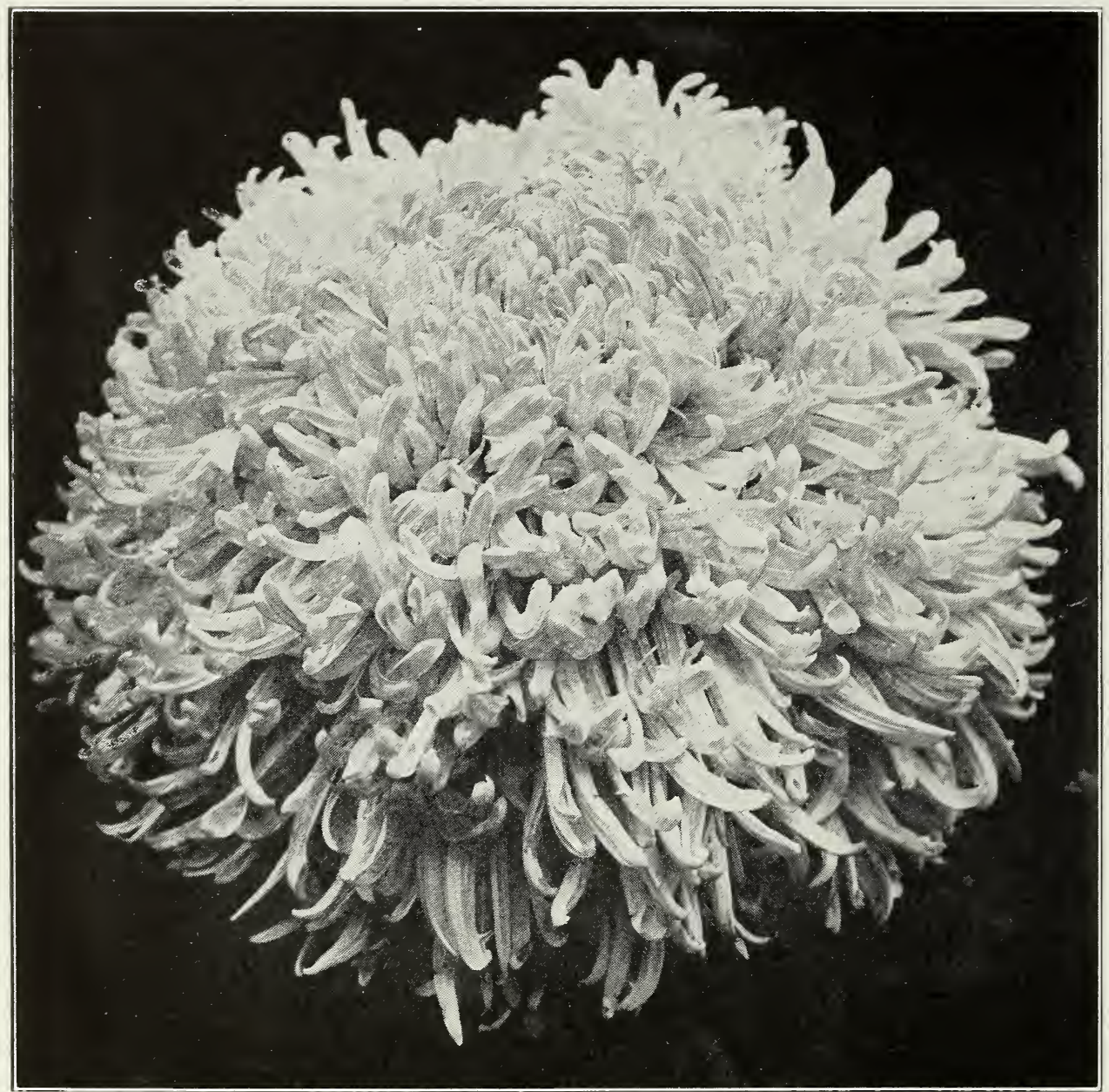

\section{Onunda.}

The gigantic white, staged by William Duckham at the American Institute. The flower photographed by actual measurement was forty-five inches in circumference and it was claimed, and I believe right, that it was easily the largest flower ever put on exhibition in America. The stem was fully equal to carrying the flower erect, which was remarkable when one considers the immense weight of the flower. This variety scored ninety-four points on the exhibition scale. The color is the weakest point, being a Lemon Yellow, but it is a gigantic thing and its size makes it a feature to be reckoned with in exhibition varieties. Price $\$ 2.00$ per plant, $\$ 20.00$ per dozen. 


\section{The Wells-Pockett Set of 1909.}

\section{Wells's Late Pink.}

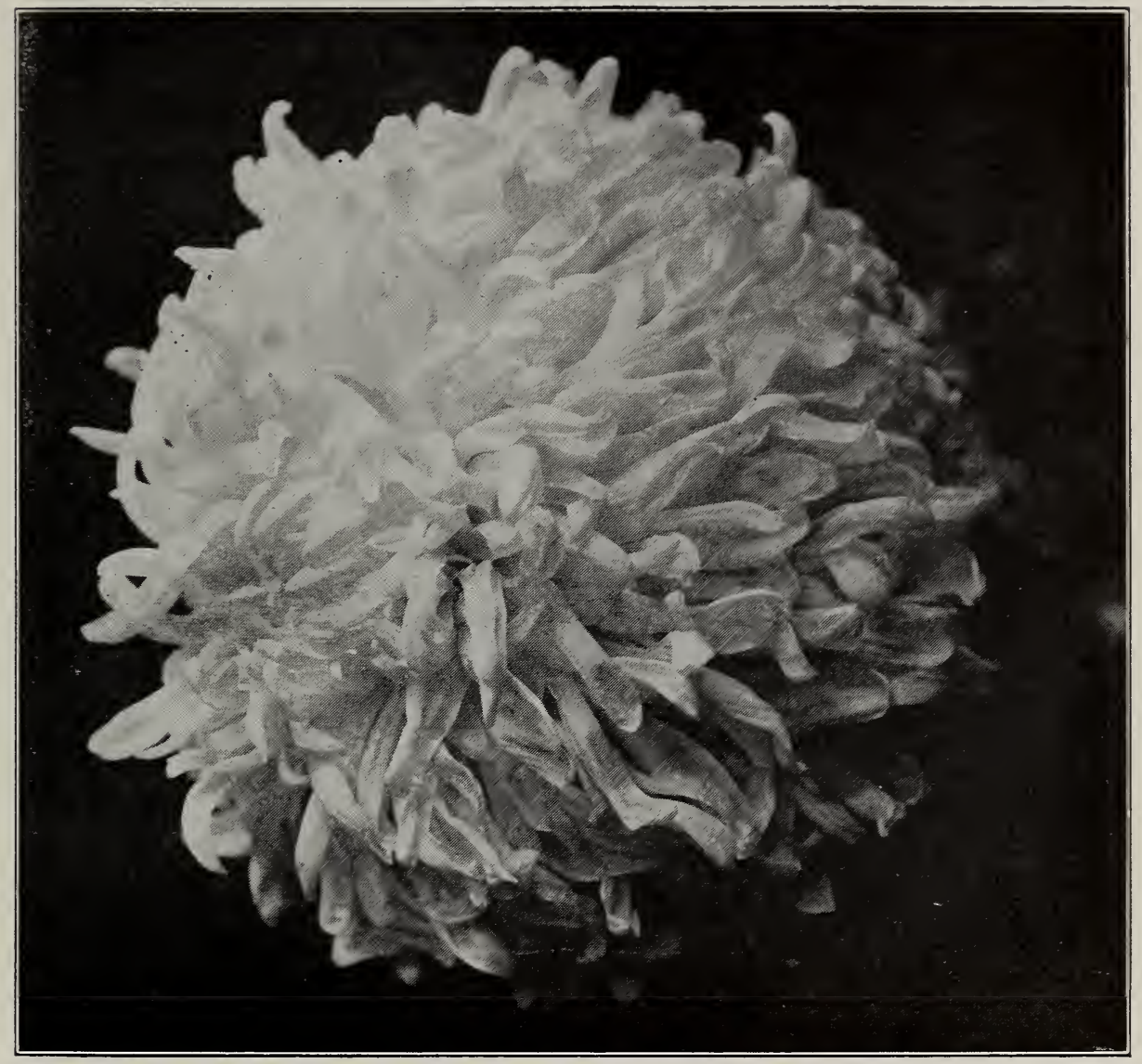

WELLS'S LATE PINK.

\section{Wells's Late Pink.}

One of the finest things sent out in many years; flower is extra large, stem and foilage absolutely perfect. Exhibition and commercial growers alike will find this a splendid flower. Price 50c each, $\$ 5.00$ per dozen, $\$ 35.00$ per 100 . 


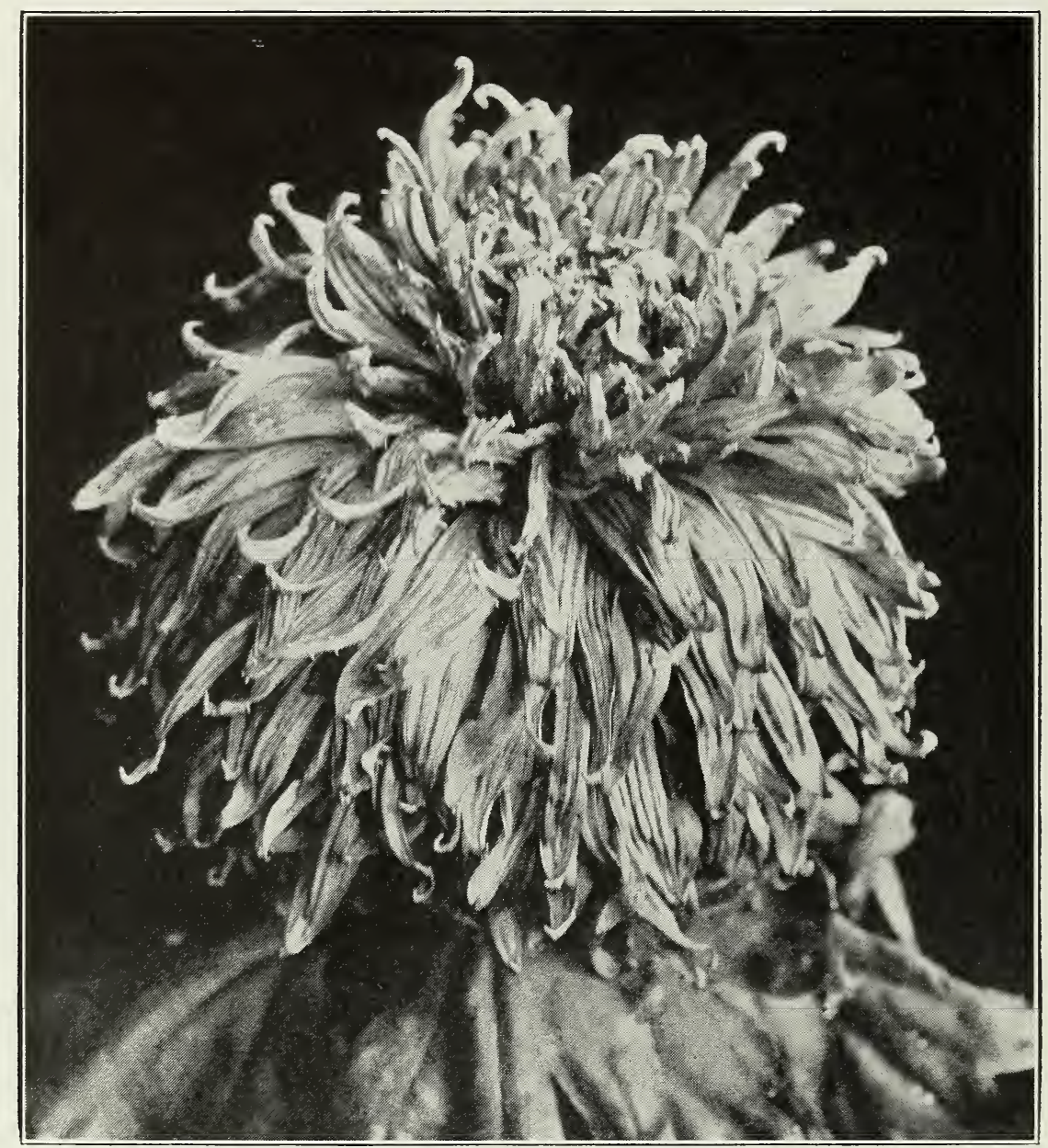

MISS MURIEL SMITH.

Miss Muriel Smith.

Salmon terra cotta, charming color, large flowers on stiff stems. By my experience with it, I cannot recommend it as an exhibition flower, as it seems to be hardly large enough, but it is one of the most beautiful varieties $I$ have ever grown. Price 50c per plant, $\$ 5.00$ per dozen, $\$ 35.00$ per 100 . 


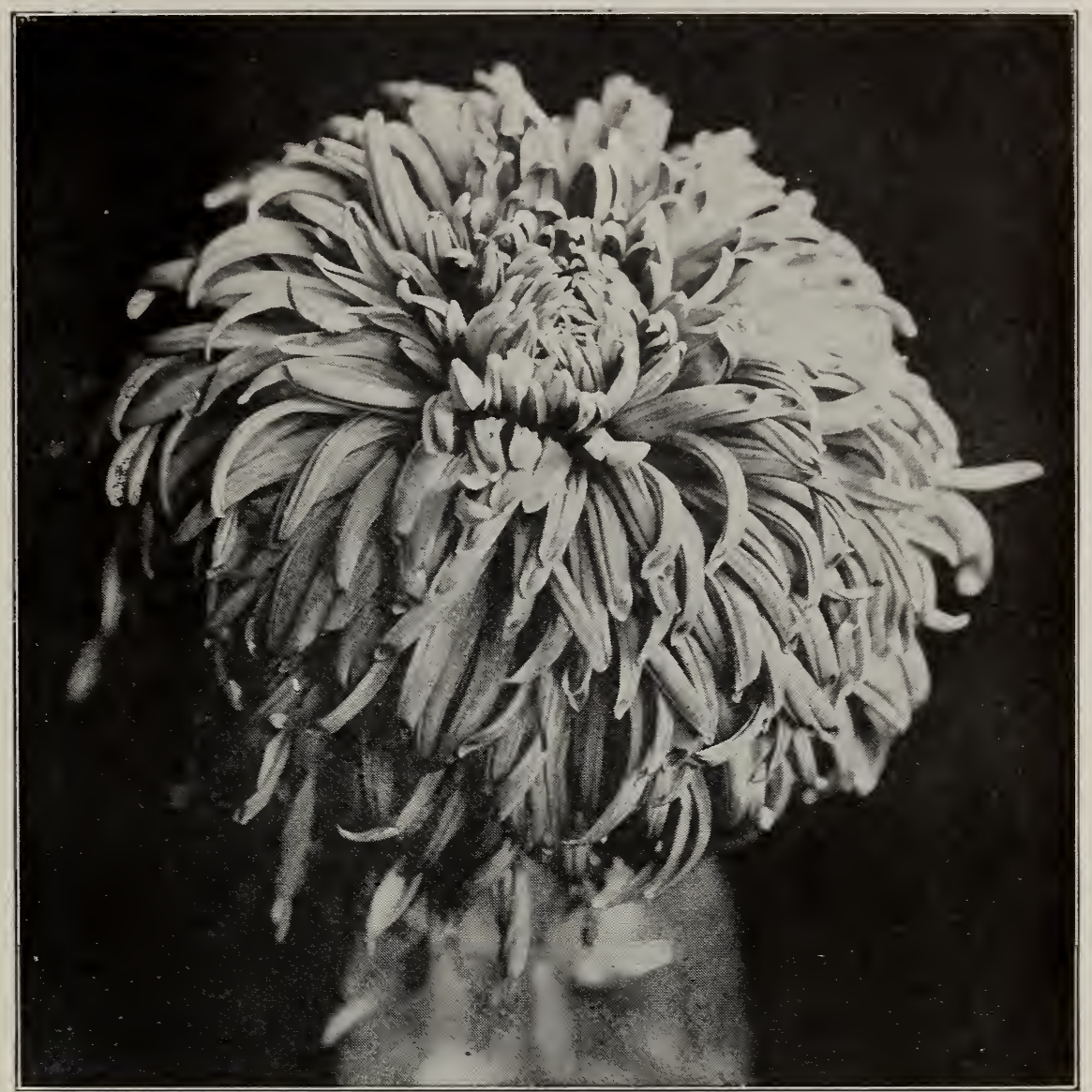

W. MEASE

\section{W. Mease.}

Bright rosy red, one of the very largest in size and a very valuable exhibition variety. This is a much better colored variety than Mary Mason, and should supersede that sort as a show flower. It is a dwarf, handsome grower and carries the foliage well up to the flower. Price 50c each $\$ 5.00$ per dozen, $\$ 35.00$ per 100 .

YELLOW IVORY. This is a yellow sport of ivory, one of the best known and largely grown commercial varieties in the country. I have a large stock of this variety and can quote early delivery at $\$ 2.00$ per dozen, $\$ 15.00$ per 100 .

YELLOW OCTOBER FROST. A yellow sport of the popular early white, identical with the parent in every way. $\$ 2.00$ per dozen, $\$ 15.00$ per 100 . 


\section{Wells-Pocket List for 1909-Continued.}

MRS. H. STEVENS. Golden salmon bronze. This is a magnificent variety and will be very popular as a show flower. Size is enormous, stem and foliage perfect. Any bud after August 15th will produce a perfect flower.

GLADYS BLACKBURN. A large, handsome flower of the Carnot type, buff color, a very easy doer and an all around good thing. Height 3 feet, crown bud for a larger flower.

CAPTAIN JULYAN. Bright primrose color, splendid grower and a very satisfactory variety to handle. When grown as a pot plant or grown as a spray, it is a very handsome variety. Comes good on any bud.

W. HOTSTON. Golden salmon. This is a splendid variety and must become very popular. Every bud produces a perfect flower. Stem is perfectly stiff and the foliage is carried right up to the flower. I cannot see a single fault with this variety as it has behaved with us this year.

R. F. FELTON. The deepest possible shade of yellow. The flower is medium in size, stem and foliage perfect, the latter being carried right up to the flower and the flower itself never damps a petal under any conditions, whatsoever. It is even deeper in color than the popular Mary Donnellan. It will unquestionably make its mark as a commercial yellow as well as an exhibition flower. Every grower should try this sterling variety.

KEITH LUXFORD. Wine red, very distinct in color. This variety is not a monster but it is a very beautiful thing and color is unique. Splendid habit.

Price on all these varieties $50 \mathrm{c}$ each, $\$ 5.00$ per dozen, $\$ 35.00$ per 100 .

W. J. HIGGS. Mahogany bronze. This is a perfect incurved flower and as a true incurved makes a large flower for its type, dwarf, handsome grower perfect in stem and foliage.

J. LOCK. A splendid exhibition yellow chrysanthemum, one of the very finest we have ever imported. Stock is limited and we will hold this variety to $\$ 1.00$ each, $\$ 9.00$ per dozen.

PURITY. Pure white, long, curling florets. A very handsome variety.

HON. MRS. LOPES. Rich golden yellow with long drooping florets. This should show up very well with more extended culture.

LADY E. LETCHWORTH. A deep yellow variety, very highly recommended and another season may show up much better.

Prices of these varieties are 50c each, $\$ 5.00$ per dozen, $\$ 35.00$ per 100 . 


\section{New American Varieties.}

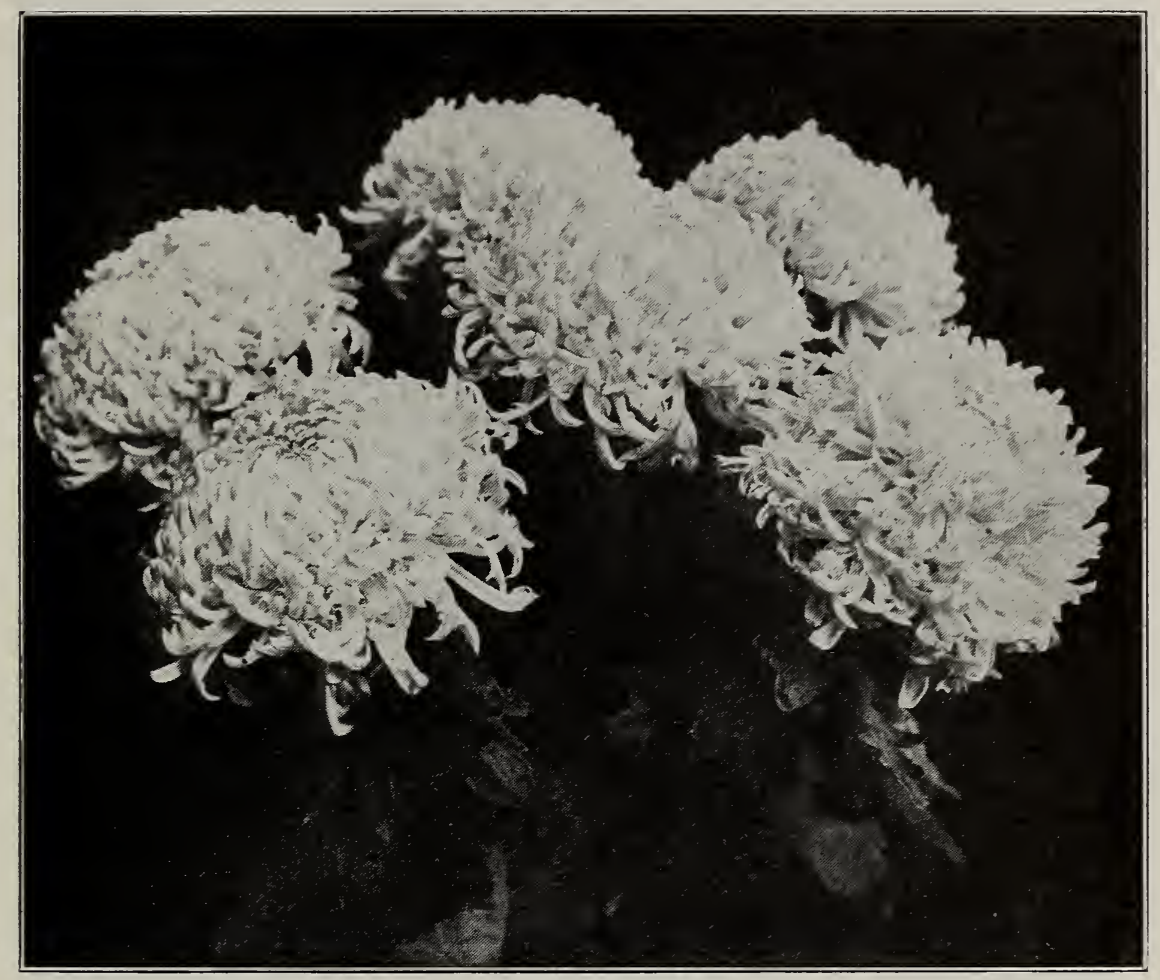

MRS. A. R. PEACOCK

\section{Mrs. A. R. Peacock.}

A "Beatrice May" seedling. This variety closely resembles its parent, saving that the stem and foliage is very handsome. The style and shape of the flower is much the same as Beatrice May, with the added advantage of perfect foliage. It is fully opened by October 7 th, though it is a splendid keeper and can be held several weeks on the plant if necessary. Certificated C. S. A. Price 50 c each, $\$ 5.00$ per dozen, $\$ 35.00$ per 100 . 


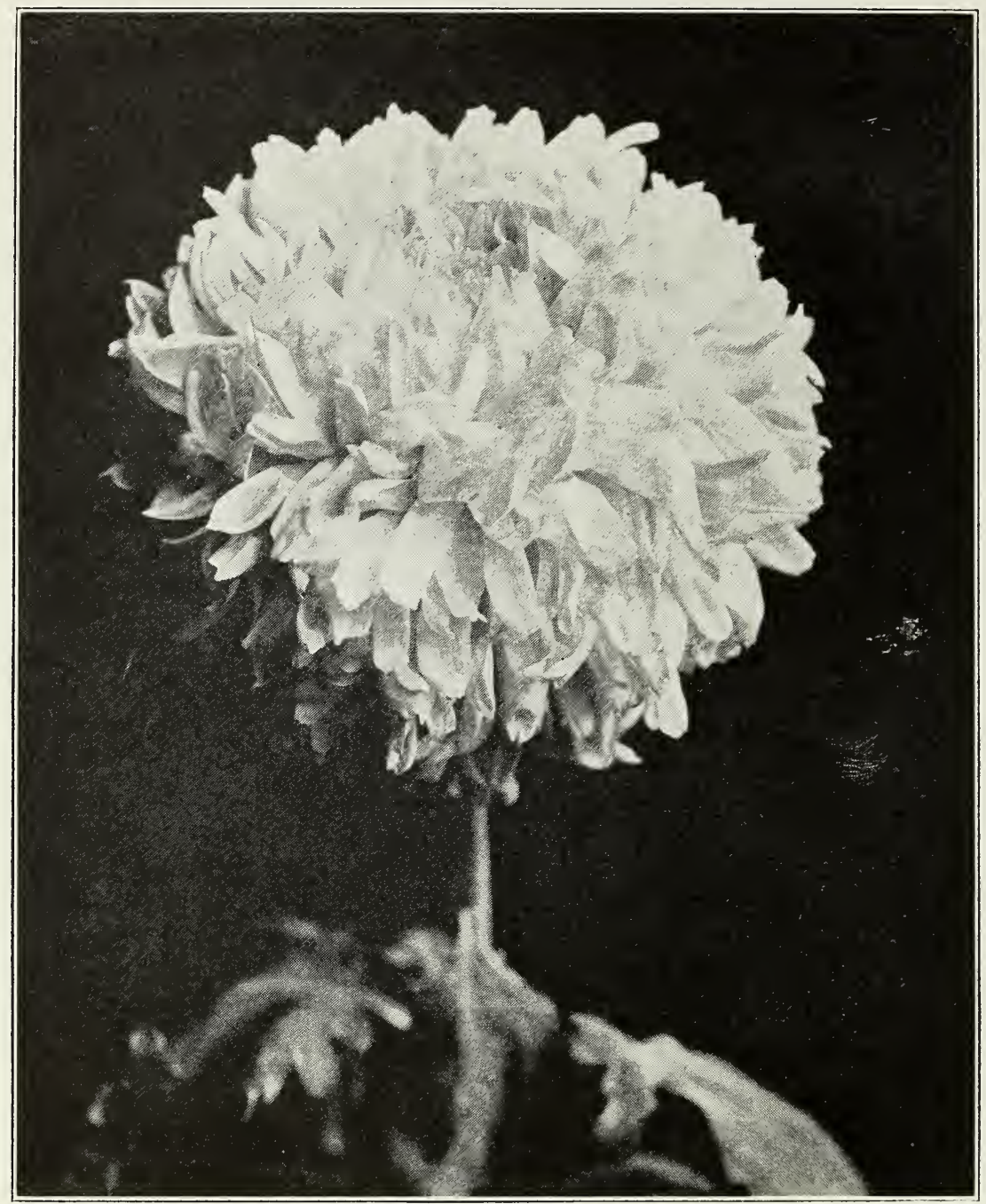

MRS. WM ARNOLD

Mrs. Wm. Arnold.

A first-class commercial white. Petals very stiff, stem and foliage perfect, flower a splendid keeper and shipper. This will not run large enough to be an exhibition flower, but as a commercial white it does not seem to have a single fault. Price 50c each, $\$ 5.00$ per dozen, $\$ 35.00$ per 100 . 


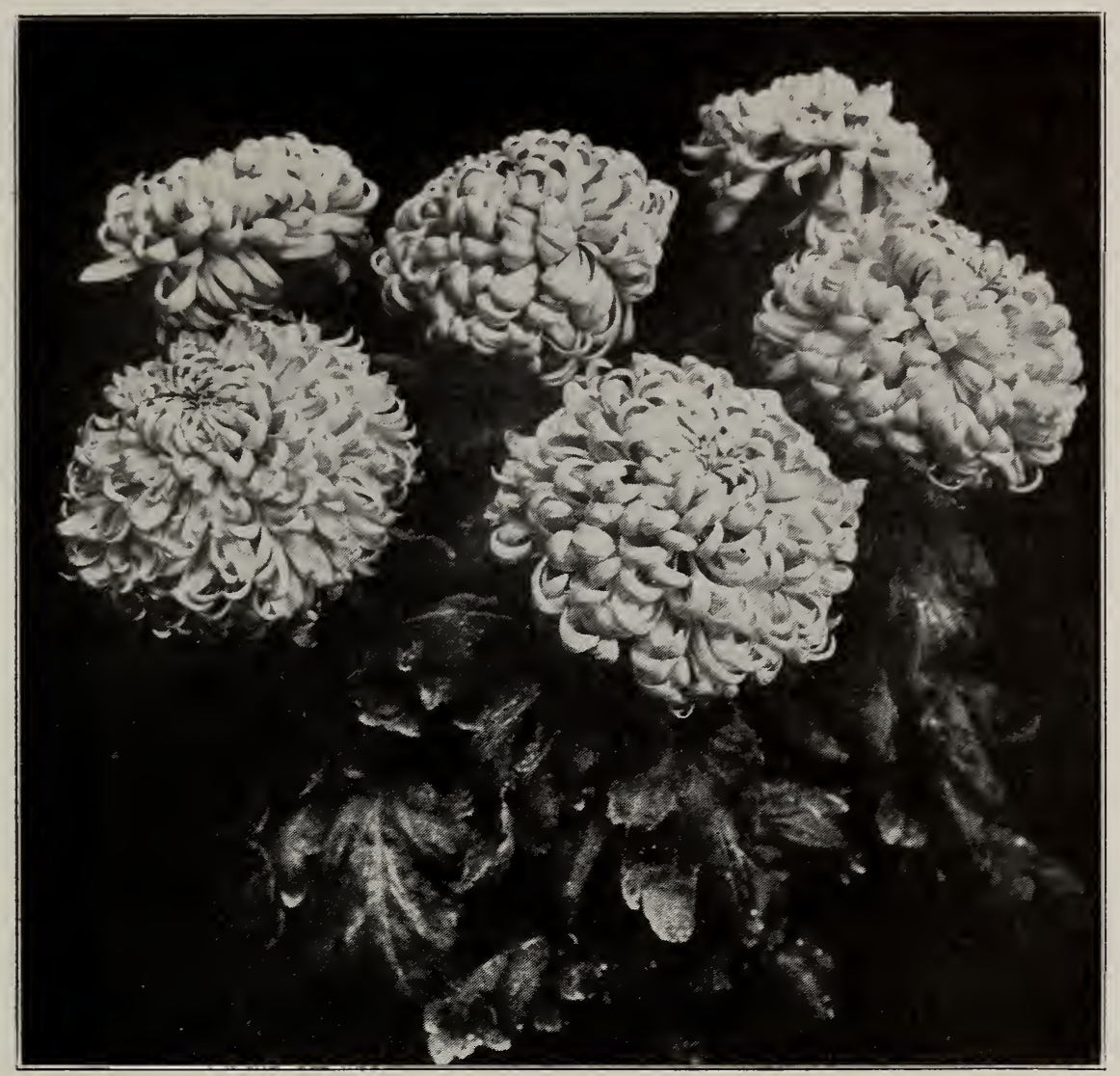

MRS. WM. WINCOTT

\section{Mrs. Wm. Wincott.}

A fine early pink. Every bud comes perfect and as a commercial pink ranks high. By its behavior with us it certainly will make a place for itself. Certificated, C. S. A. Price 50c each, \$5.00 per dozen, \$35.00 per 100. 


\section{Nine Varieties.}

The following varieties have not shown any merit with our conditions, and while we can supply them we feel that we cannot recommend them:

$\begin{array}{lll}\text { Exquisite. } & \text { Mrs. H. Preston. } & \text { Mrs. J. L. Burgess. } \\ \text { Master James. } & \text { Miss Annie Nichol. } & \text { Crimson Gem. } \\ \text { Master David. } & \text { Sir Frank Crisp. } & \text { Bryant's Beauty. }\end{array}$

\section{Elmer D. Smith \& Co.'s Novelties for 1910}

DONATELLO. While this variety is not a counterpart of Monrovia, it is in many respects an improvement. Color bright yellow, slightly incurving with good stem and foliage and excellent substance. Especially adapted to those who bench their plants late as it will produce double flowers from late buds, $3 \frac{1}{2}$ feet fully matured October 20th. Best bud August 20th. C. S. A. Cert.

Price 50c each, $\$ 4.00$ per ten, $\$ 35.00$ per hundred.

OROBA, A large early white in the way of Beatrice May, being of the easiest culture with fine stem and foliage. It may not excel B. May in size but its other splendid characteristics are so much superior that it will soon gain ascendency with the Commercial grower. 3 feet ready October 20th. Best bud August 15th. C. S. A. Cert.

Price 50c each, $\$ 4.00$ per ten, $\$ 35.00$ per hundred.

TONKAWA. Deep golden yellow Japanese reflexed with bronzy shadings. The foliage is produced very close to the bloom and the stem is the very best. Those requiring a midseason golden bronze will not be disappointed. 4 feet. Best bud September 1st, ready October 25th. C. S. A. Cert.

Price 50c each, $\$ 4.00$ per ten, $\$ 35.00$ per hundred.

\section{Exhibition Varieties.}

NAOMAH. Large Japanese incurved. A seedling from Merza more conical in form than its parent. If the stem were a little more rigid this would be an ideal commercial sort as it possesses every other qualification and may prove very acceptable to those who plant early and give generous treatment. Pure white. 4 $1 / 2$ feet. Ready November 1 st. Bud August 25th.

Price $75 \mathrm{c}$ each, $\$ 6.00$ per ten, $\$ 50.00$ per hundred.

RANDEE. A large ball shaped Japanese belonging to the exhibition section. The early buds come pure white and the later ones are shaded pink. Fetals toothed at the extremities and rather irrgular in their arrangement. Bud August 25 th. $3 \frac{1}{2}$ feet. Heavy stem and foliage. C. S. A. Cert.

Price $75 \mathrm{c}$ each, $\$ 6.00$ per ten, $\$ 50.00$ per hundred.

ADONIS. A light pink of a slightly deeper shade than Gloria. The narrow petals reflex and interlace forming an artistic bloom of the largest size in which the depth exceeds the diameter. Height 5 feet. Best bud, August 25th. C. S. A. Cert.

Price 75 c each, $\$ 6.00$ per ten, $\$ 50.00$ per hundred. 


\section{Single Varieties.}

ARLEE. A rich golden amber of dwarf sturdy growth excellent either as a pot plant or for cutting. Is a true single of the large flowering section producing large sprays which are borne erect.

Entirely distinct and of exceptional merit. C. S. A. Cert.

Price $25 \mathrm{c}$ each, $\$ 2.00$ per ten, $\$ 15.00$ per hundred.

ITASKA. Properly defined this variety is a semi-double incurved, but being so near single we have included it in this section. A seedling from A. J. Balfour but a few shades lighter. The incurving petals give the flowers the appearance of Pond Lilies and being a most pleasing shade of pink are very useful for decorative work.

Price $25 \mathrm{c}$ each, $\$ 2.00$ per ten, $\$ 15.00$ per hundred.

\section{Pompon.}

CLORINDA. Semi-dwarf producing erect sprays of an even shade of Bronze. C. S. A. Cert.

Price $25 \mathrm{c}$ each, $\$ 2.00$ per ten, $\$ 15.00$ per hundred.

\section{Last Year's Novelties.}

This list contained some wonderful varieties that swept the shows the past autumn. Price $20 \mathrm{c}$ per plant, $\$ 2.00$ per dozen, $\$ 15.00$ per 100 .

BESSIE EVANS. A very strong grower and makes an enormous flower with foliage well up. Color, light pink. This is a true Jap and made a good showing with everyone. Any bud.

CHARLES H. TOTTY. Named by Wells in England. This is a top notcher. Flower stem and foliage are alike, enormous. Color is a glowing chestnut scarlet. This will displace the popular Dunne as it is far brighter in color and even larger in size. Height 4 to 5 feet. Any bud after August 15th.

CLARA WELLS. A true incurved type. This should be a commercial variety as it will travel anywhere without getting bruised and is a splendid keeper. Color is a pale yellow. Stem and foliage beautiful. Height 3 feet.

FREDA BEDFORD. This is only a medium-sized flower and will do best grown as a pot plant and carrying 6 to 12 flowers. Its habit is ideal as a pot plant and the color, a bronzy orange, is very effective.

FRANK PAYNE. A light pink Jap, reflexed. A heavy grower and good stem. Height 3 to 4 feet. Crown bud August 10th onwards.

GEORGE MILEHAM, 1908. A bronze yellow. Height 3 feet. Bud August 10th and later.

G. W. POOK. A salmon terra cotta. Splendid grower and neat, attractive flower. Well worth growing by the exhibitor as the color and shade of the flower are distinct. Height 3 to 4 feet. Any bud after August 10th.

GLORIA (Smith). A seedling of October Frost producing double flowers from any bud. Those selected August 25th to September 5th finish 
October 10th to 25 th, producing large blooms of a beautiful light pink same as seen in the Enchantress Carnation. Stem and foliage unsurpassed.

GOLDEN KING (Lotze). A bright golden yellow seedling, perfect stem and foliage and fine keeper and shipper. Three feet tall. A fine commercial flower, ready to cut October 15 th.

LILLIAN COPPARD. The earliest red we have at present. This was in fine shape October 3rd last year. A splendid grower and very attractive flower. Height 4 feet.

LESLIE MORRISON. Rosy crimson. An enormous flower and a very strong grower. This is one of the largest flowers of the season.

MERSTHAM BLUSH. Flesh white in color. A beautiful grower and fine in every way. Height 4 to 5 feet. Bud after August 10 th.

MRS. L. THORNE. A lovely canary yellow of full size, dwarf habit, splendid foliage and an easy grower.

MRS. O. H. KAHN. A bronze with a record. Won first in commercial and exhibition seedling classes at Chicago. Come good on any bud early or late, and is absolutely reliable. It will become a universal favorite. Height 3 to 4 feet.

MRS. J. W. SCOTT. This variety has been grown for years by one firm for Convent Garden market, where it commanded the highest price as the eariest commercial white and made considerable money for its owners. I offer it to be grown as a pot plant carrying several flowers, or planted closely as a commercial cut bloom only as it is not up to exhibition size and finish.

MRS. CHARLES H. TOTTY. A beautiful and refined flower. Color Hopetown pink. Do not take buds before August 20th as early buds show a green tendency. Height 3 to 5 feet.

MRS. J. W. MAKANT. Ivory white Jap with very thick petals. Dwarf and robust.

MRS. J. HYGATE. An English seedling that much resembles W. M. Moir, but has less neck.

MLLE. MARGUERITE DESJOUIS. A snow-white French variety that shows good promise as a commercial cut flower. Is evidently a keeper and shipper. The stem is fine and stiff and foliage good.

MLLE. HELEN PRUDHOMME. Ready October 10th. Rosy white and lavender, very dainty in color, semi-dwarf with stiff stem and elegant foliage.

POCKETT'S SURPRISE. Rosy crimson with cinnamon bronze reverse. This is truly a surprise to the grower, for the flower is immense in size and yet is easily held up by the splendid stem. One of the best things that noted grower has sent us. Do not take bud too early. August 20 is early enough. The flowers from earlier buds incurve too much, showing the bronze, but in later flowers the petals fall back and show the true crimson color.

POCKETT'S CRIMSON. The grandest thing in its color ever sent out. 
Crimson with a gold reverse, makes a flower 9 inches across. Splendid grower, foliage up to flower. Height 4 feet. Bud August 15th onwards.

PRESIDENT TAFT. Japanese incurved, petals of the purest white which closely incurve forming a glistening ball. Stem and foliage ample. Four and one-half feet. Best bud August 20th, which matures October 25th.

ROSE POCKETT. Another flower for the collections that will be found invaluable. The color is old gold and the petals stand straight out, showing the color to the best advantage. It has every desirable attribute of size, form and finish. Every exhibitor who figures on a short stem class of 24 or more kinds should grow this variety. Early bud.

SPLENDOUR. Bright red with old gold reverse. Most of the petals curve upwards and the effect is old gold in color, with here and there a red petal showing. As a distinct variety it is well worth growing.

YELLOW MILLER. A yellow sport of the bronze Mrs. J. A. Miller. This is a very popular variety as the parent is one of the largest flowers and best growers we have. Growth and treatment identical with the parent in every way.

W. R. BROCK. A splendid late commercial pink for Thanksgiving and later. An ideal flower for shipping and a fine keeper. Foliage up to flower and stem A 1. Comes best from September buds.

\section{Standard Varieties.}

This list includes every variety of value in standard kinds. Many others can be supplied if asked for.

Prices are 10c per plant, 75c per dozen, $\$ 5.00$ per 100 .

AMATEUR CONSEUL. Crimson, good commercial kind.

ALICE BRYON. Second early white, largely grown.

ANDREW MCKENDRY. Warm cerise bronze, early variety.

BEN WELLS. Flesh color, very large flower.

BLACK HAWK. Very deep crimson.

BESSIE GODFREY. Canary yellow, exhibition kind.

BEATRICE MAY. Splendid white, sometimes shaded pink.

BRUTUS. Bronze, fine as a pot plant.

COL. APPLETON. The best known yellow.

CHELTONI. Yellow sport of Nellie Pockett.

C. MONTIGNY. Lemon yellow, a grand flower.

CLARKS GOLDEN THOMPSON. A good yellow commerial variety.

CLEMENTINE TOUSET. Second early white.

CHAS. WEEKS. Salmon and red.

COMOLETA. Early yellow commercial.

CROCUS. Early yellow, very good.

DAPHNE. White sport of Mrs. Coombes.

DR. ENGUEHARDT. A good commercial pink.

DAKOMA. Bronze, with lighter reverse.

DIRECTOR GERARD. Golden yellow, early variety.

DUB. FOUBERT. Deep yellow, unique form.

DICKEY VINCE. The yellow sport of Mrs. F. F. Thompson.

D. GOLDSMITH. Bronzy yellow; petals hang straight down.

EARLY SNOW. Early white.

ETHEL FITZROY. Beautiful bronze.

F. A. COBBOLD. Late pink, fine variety.

F. S. VALLIS. The largest yellow in cultivation. 
GLENVIEW. A splendid bronze.

G. J. BROOKS. Purple crimson.

GENERAL HUTTON. Yellow, fine but tall grower.

G. S. KALB. Early yellow, good commercial.

GLORY OF THE PACIFIC. Early pink, largely grown.

GOLDEN WEDDING. Fine old late yellow.

GEORGE KALB. Early white.

GRACE WITNEY. Enormous pink, dwarf grower.

GOLDEN GLOW. The finest early yellow we have.

HARRISON DICK. Orange and red.

LYNNWOOD HALL. Pure white, like Convention Hall.

LADY HOPETOWN. The largest pink in sight.

LADY TALBOT. An immense light yellow.

LADY NORTHCOTE. White, heavy flower.

LEILA FILKINS. Pink, beautiful stem and foliage.

LEON TRUELLE. Creamy white, early variety.

MAUD DEAN. Late pink, good commercial variety.

MARY DONNELLAN. The finest shade of yellow.

MARY INGLIS. An immense bronze.

MAJOR BONNAFFON. Yellow, very largely grown.

MARY MASON. A gigantic bronzy red.

MISS MAY SEDDON. Beautiful dwarf, white.

MISS CLAY FRICK. The white sport of W. Duckham.

MISS M. HANKEY. Late pink, splendid grower.

MORTON F. PLANT. Very large pink.

MONROVIA. The best early yellow.

MRS. ROBINSON. White, largely grown.

MRS. GIRARD FOSTER. Creamy white, commercial type.

MRS. R. H. HAGGARD. Milk white petals, hang straight down. cultivation.

MRS. NORMAN DAVIS. A magnificent white, possibly the best in

MRS. W. WELLS. Small flower, lovely color, deep orange.

MRS. J. C. NEILL. Much like Cheltoni, but larger.

MRS. A. H. LEE. Crimson, a good free grower.

MRS. A. T. MILLER. White, take an early bud to get heavy flower.

MRS. GEO. HUNT. Light yellow, a monster when well done.

MRS. H. BARNES. Old rose, terra cotta shading.

MRS. R. FORDERER. Creamy yellow, amber shading.

MRS. G. BEECH. Yellow sport of Mrs. Swinburne.

MRS. G. HEAUME. Salmon bronze.

MRS. COOMBES. Fine second early pink.

MRS. J. A. MILLER. Bronze red, enormous flower.

MRS. D. V. WEST. Immense white, poor stem.

MRS. E. BECKETT. Reflexed white.

MRS. J. TRANTER. Fine white for pot plant.

MRS. D. WILLIS JAMES. Chestnut, small but beautiful.

MRS. F. F. THOMPSON. Cream white, very beautiful but necky.

MRS. H. PARTRIDGE. Crimson, a grand thing.

MRS. J. E. DUNNE. Old rose, one of the largest.

MRS. SWINBURNE. Late white, good commercial flower.

MRS. W. DUCKHAM. Golden yellow, late buds, striped crimson.

MRS. W. KNOX. Lovely yellow.

MRS. T. W. POCKETT, Early yellow. 
MERZA. Still unequalled in white.

MORTON F. PLANT. Very large pink.

MONEYMAKER. A good white for pot work.

M. G. RIVOL. Bronze sport of M. Radelli.

M. EMILE DAVID. Loose incurved, flesh pink.

MLLE. J. NONIN. Late white, can be got for Christmas.

MLLE. A. LAURENT. Fine clean white.

MLLE. A. DETROYAT. Incurving light pink.

MLLE. SUSANNE GAUTHIER. Pure white, flat petals.

MLLE. J. ROSETTE. Late pink.

MLLE. SIMON JOSSIER. Cream white, very large.

MERSTHAM RED. Fine commercial red.

M. LOISEAU ROUSSEAU. Enormous pink.

NAGOYA. Late yellow.

NELLIE POCKETT. Creamy white, still a grand variety.

OLD GOLD. Orange yellow, fine for pots.

ONGAWA. Salmon bronze, very large.

OMEGA. Early yellow.

OCTOBER FROST. Early white, take an early bud.

OCTOBER SUNSHINE. Early commercial yellow.

O. H. BROOMHEAD. Rose pink, a very fine variety.

PRESIDENT FALLIERES. A fine white variety, good grower.

POLYPHEME. Splendid yellow, a first-class sort.

PETITE RENEE. Red and bronze, very large.

PACIFIC SUPREME. An improved Pacific.

PRESIDENT VIGER. Deep rose, one of the big fellows.

POLLY ROSE. White, sport of Pacific.

PRESIDENT LOUBET. Early white.

ROSERIE. Early pink, a moneymaker.

ROI. D. ITALIE. Yellow, good commercial kind.

REGINALD VALLIS. Deep rose, long narrow petals.

S. A. NACEUR-BEY. Yellow, a very fine exhibition variety.

SOUV. SCALARANDIS. Golden yellow, beautiful pot plant.

T. EATON. Commercial white.

VALERIE GREENHAM. Enormous exhibition pink.

VIRGINIA POEHLMANN. Second early white.

W. WELLS. White Japanese, long florets.

W. DUCKHAM. Splendid pink.

WHITE CLOUD. Early stiff stem, white.

WILLOWBROOK. Early reflexed white.

WINTER CHEER. Closely incurved, beautiful pink.

\section{Ostrich Plume}

\section{or \\ Hairy Varieties.}

10c each, \$1.00 per dozen, \$6.00 per 100 .

ENFANT DES MONDES. White sport of Boehmer.

LOUIS BOEHMER. Pink, the best known hairy sort.

LEOCADIE GENTILIS. Yellow sport of Boehmer.

F. J. TAGGART. A yellow type, tall grower, flower generally bent over, very large. 


\section{Single Varieties.}

My stock of singles is the largest in this country and I add the best things of Europe yearly. The following novelties are very fine indeed and show great progress in size and rich coloring.

Price 25 c per plant, $\$ 2.50$ per dozen.

AUTUMN, $l$. The name will describe the color, for there are all the shades of autumn foliage in each flower. These are best disbudded, or there is the appearance of "too much flower"; early November, $31 / 2$ feet.

G. W. FORBES. Splendid late crimson.

HAROLD SLADE, m., deep bronze tipped gold, similar make to Mary Anderson, long, stiff stems; November.

H. M. SMITH, l., lilac mauve with pure white ring round dics, stiff stems and very free.

JESSIE CURTIS, l., deepest crimson, a splendid bold flower which attracts attention at sight. Early November.

LAURIE HEARN, $l$., crimson maroon with white ring round disc. Best as sprays, but if disbudded they must be terminal buds, or the color is not so good. Very free.

MARGUERITE PINK, s., golden buff. The flowers are similar in make and size to Mary Anderson, but the stiff stems carry three flowers well divided at the end of each stem; they need no disbudding at all.

MERSTHAM JEWEL, $l$., reddish terra cotta with a gold centre and points. One of the most beautiful singles we have ever seen; the flowers are well divided on the sprays, so disbudding is immaterial.

MERSTHAM TINTS, s., soft yellow with shades of bronze towards the edges of the florets. They are delightfully pretty, the flowers being quite round and flat; mid-November.

MORWENNA. This is best described as a single Source d'Or, and is purely a decorative variety. The flowers are well divided with four or five to a stem, and will be the table decorator's delight. Wonderfully prolific.

METTA. Deep magenta with white zone.

CHAS. GRAVES. Light yellow, very large.

NELLIE RIDING, s., reddish salmon, best described as a true single Mary Richardson, and flowers in long, beautiful sprays in the open ground early in October. Four feet.

PETER PAN, s., fawn color, has sprays of flowers about 9 inches long, with twelve or fifteen dainty starlike flowers on the stem, all opening at the same time, forming a natural ladies' spray, and each plant will carry a dozen or more sprays.

SLYVIA SLADE, $l$., rosy garnet with broad pure white ring round the disc, as true as a Cineraria flower. The habit and freedom of flowering is superb. Gained the F. C. C. at the N. C. S., and A. M. at the R. H. S. Early November, 3 feet.

\section{Singles - Standard Varieties.}

These plants should be grown naturally without any disbudding to speak of and then they make splendid decorative plants in pots or as cut sprays from the bench.

Prices are $15 \mathrm{c}$ per plant, $\$ 1.25$ per dozen, $\$ 10.00$ per 100 . My selection $\$ 8.00$ per 100 . 
ALICE COOMBER. Salmon bronze, with yellow ring.

ALBERT WILLIAMS. Golden amber, very beautiful.

ANNIE BETTS. Light pink, should be disbudded on lower shoots.

ANNIE STEVENS. Rose pink, just a mass of bloom.

ALICE SUPP. Clear pink, most beautiful quilled.

ADELAIDE. Deep blush, with pure white zone.

ALICE CRATE. Rose pink, white eye, certificated C. S.

AMBER QUEEN. Amber yellow, short grower.

ARTHUR HORNE. Clear yellow, very free blooming.

ANNA SPANGLE. Pure white dwarf and beautiful.

ANNA. A seedling from Indicum or Golden Chain, possessing the same freedom of bloom but not as slender and rampant in growth as the parent.

ANNA SPANGLE. Pure white dwarf grower.

BIDDY. Salmon pink, early variety.

BESSIE KENNEDY. Deep blush, yellow eye, very dwarf.

BELLE OF WEYBRIDGE. Chestnut terra cotta, fine grower.

BESSIE PAYNE. Bright clear pink, early flowering.

BLANCHE. Lovely light pink, October flowering.

CROWN JEWEL. Rich bronzy yellow, a large and beautiful flower.

CECIL DENYER. Milk white, flowers look like a small cactus dahlia.

EARLSWOOD BEAUTY. Primrose, with large bold eye.

EDITH HARLING. Canary yellow, splendid thing.

EMILE. Bright pink, October flowering.

ETHEL BEER. Dwarf bronzy red.

ENA REIMER. Terra cotta, one of the best.

FELIX. Crimson bronze, large flower, one of the best.

F. W. SMITH. Rich pink, dwarf habit, very fine style.

GERTRUDE. Pure white, disbud a little.

in its color.

GOLDEN STAR. Rich yellow, bright orange disc. One of the best

GLADYS. White star-shaped flowers.

GRACIE LAMBERT. Deep pink, a beauty.

GRETCHEN. Pure white, green eye, beautiful effect.

GUY WESTLAKE. White; narrow cactus petals.

HAROLD BISHOP. White, makes wonderful display.

HILDA. Orange terra cotta, most distinct.

HELEN TOTTY. Cerise shading to red, very brilliant, in every way

a grand thing. Best as a specimen plant.

HAROLD SHAW. White tips of the petals tinged with pink.

H. S. BEVINS. Bright crimson, fine in its color.

HERBERT HENDERSON. Deep blush; makes a fine bush plant.

INDICUM. Small yellow; the original Chusan daisy.

J. T. ANGUS. Rosy cerise, very fine late variety.

JULIUS ROEHRS. Chestnut shading to bronze.

KATHLEEN BUNYARD. Yellow, pretty star-like flowers.

KITTY BOURNE. Charming yellow, stiff stems.

KATIE COVELL. Maroon, stiff erect petals.

LINTON. Blush on cream colored ground; a splendid thing.

LADYSMITH. Rich pink, very free bloomer, dwarf habit.

LILY BEER. Yellow, long light spray of flowers.

LESLIE. White, tips of petals pink.

LILY VALENTINE. Deep terra cotta, most distinct.

LORNA DANDO. Charming late pink. 
MARY RICHARDSON. Reddish salmon, one of the most distinct.

MARVEL. Bright pink; certificated.

MERSTHAM WHITE. Large pure white.

MISS A. HOLDEN. Light yellow, beautiful shape.

MISS E. PARTRIDGE. Deep pink, pretty in sprays.

MISS IRENE CRAGG. Perhaps the best pure white.

M. J. CALISLE. Fine white, wonderfully free.

M. J. OSBORNE. Large pink, white eye.

MRS. BAILLIE. Chestnut bronze, fine for bush plant.

MISS T. C. WARDEN. Pure white, makes fine long sprays.

MRS. E. ROBERTS. Blush, one of the very best and largest.

MRS. E. A. ISAACS. Blush, large, distinct and beautiful.

MRS. S. UNTERMEYER. Magnificent pink, splendid habit.

MRS. W. TURNER. Large handsome flower, makes a fine standard plant, light pink.

NANCY PERKINS. Purest white, perhaps the best of all the whites.

NELLIE COPPARD. Rosy purple, white eye.

PRETORIA. Deep yellow, green center, very strong grower.

ROSALINDE. Soft white, large and sweetly scented.

RENE des ROSES. Bright pink, a beautiful thing.

ROB ROY. Blush on white ground, very light.

THIRZA SANDFORD. Very dwarf grower, beautiful star-shaped white.

WYNDHAM. Pure white, flat florets, a gem.

WINNIE SHERRING. Apricot, beautiful flowers.

\section{Early Flowering Chrysanthemums.}

These chrysanthemums are grown by the acre in England for September flowering and give a return altogether out of proportion to the small amount of labor bestowed on them. In my own garden they made a splendid show from September 15th to the 20th of October, and I wish everyone would try a plant or two in the open ground without disbudding and the result will be a delightful surprise.

I am importing a large collection of these varieties and can quote on many other kinds in the spring.

The following ten varieties have all done finely and may be depended on the northern parts of the country at least to produce good results. There are several of them sports of Mlle. Marie Masse, a variety too well known to every British gardener to need any description.

Prices per plant 25c, \$2.50 per dozen, \$10.00 per 100 .

CRIMSON MARIE MASSE. A crimson sport.

RALPH CURTIS. Creamy white sport of M. Masse.

HORACE MARTIN. Deep yellow sport of Masse. This is in all respects a splendid variety.

MLLE. MARIE MASSE. The best known early flowering variety beautiful lilac mauve.

ROBBY BURNS. A rosy cerise sport of Masse.

WHITE QUINTUS. Pure white, the best thing in its color.

M. CASIMIR PERRIER. White tinted pink, very dwarf. Grand for pots.

LOUIS LEMAIRE. Beautiful golden yellow. Splendid dwarf habit. 
CORONATION. Creamy white. Dwarf and one of the earliest.

GOACHERS CRIMSON. Bright crimson, very fine.

\section{New Japanese Anemone. Yellow Garza.}

A seedling from Garza identical in every way except color, which is a clear yellow. I see no reason why this variety should not become as popular as Garza deservedly is, for it has the same beautiful habit and stiff stems.

Price 25 c per plant, $\$ 2.50$ per dozen.

\section{Japanese Anemones.}

These are possibly the most striking of any of the numerous types and attract attention everywhere. Price $10 \mathrm{c}$ each, $\$ 1.00$ per dozen, $\$ 6.00$ per 100 .

LE CHALONAISE. Citron yellow, very large.

SOUV. DE DOROTHY SOUILLE. Light rose, blush centre.

SOUV. DE MME. BLANDINIERE. Light crimson tipped.

SOUV. DE NORGIOTS. Cream white.

GARZA. White, the best known sort.

SURPRISE. Pink, the best of the set.

MARCIA JONES. Pure white, largest size.

MRS. BASSETT. Rosy lilac, rose and yellow.

QUEEN ELIZABETH. Silver blush with rose center.

TAM O' SHANTER. Rosy lilac, center florets edged yellow.

MDLLE. CABROL. Rosy blush lilac centre.

SIR WALTER RALEIGH. Pale blush.

\section{Carnation Novelties for 1910.}

ALMA WARD. This beautiful carnation is pure white except during dark weather when it shows delicate splashings of pink similar to the Cattleya Orchid, increasing its popularity.

Alma Ward is the largest and most fragrant carnation ever grown, producing perfect flowers $3 \mathrm{I} / 2$ to $4 \mathrm{I} / 2$ inches in diameter on strong, erect stems 36 to 42 inches in length.

This most remarkable variety takes the same place among carnations as the American Beauty Rose among roses, and has, during the past four years, been awarded numerous prizes, including the following:

The Lawson Silver Medal. . . . . . . . . . . . . . . . Toronto, 1907

(No gold medal having been awarded.)

The Lawson Gold Medal..................Washington, 1908

The American Florists' Society Silver Medal..........Washington, 1908

Rooted cuttings ready January 1 st. $\$ 3.50$ per $12, \$ 6.00$ per 25 , $\$ 10.00$ per $50, \$ 20.00$ per 100 .

\section{Mrs. C. W. Ward.}

MRS. C. W. WARD is a perfectly formed flower with full centre; color deep pink several shades lighter than Lawson, deeper than Winsor, having strong, erect stems 24 to 36 inches in length. A vigorous, healthy grower and has never shown disease of any kind.

A very early and free bloomer, producing fine flowers as early as September 1 st, which bring from twenty-five to fifty per cent. more than any other variety on the market. 
The keeping qualities of this variety are remarkable. Several shipments of blooms sent to Europe reached their destinations in perfect condition, and wherever exhibited it has always been the last to show signs of wilting.

\section{Awards.}

American Florists' Society Silver Medal.............................. 1906

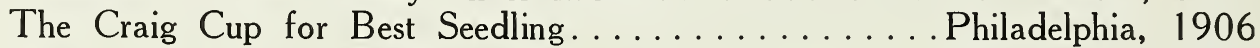
The Lawson Bronze Medal. . . . . . . . . . . . . . . . W Washington, 1908 The Horticultural Society of N. Y. Silver Medal,

Sweepstake prize for best 100 blooms.........New York, 1909 The Horticultural Society of N. Y. Diploma

For best new variety.................. Yew York, 1909

Rooted cuttings ready December 15 th. $\$ 3.00$ per $12, \$ 15.00$ per 100 , $\$ 120.00$ per 1,000 .

\section{New Carnation Mary Tolman.}

\section{COLOR}

Deep flesh pink, a shade deeper than a very highly colored Enchantress, the color extending evenly all over the petals. Does not fade in the bright weather.

FORM

Resembles the well-known variety, Gov. Wolcott, making it a very attractive exhibition and commercial variety. Flowers 3 to $3 \frac{1}{2}$ inches. HABIT

A strong grower, free from disease, and not inclined to be grassy, but gives plenty of cuttings, which propagate very easily. The grass is hard, thus resisting disease. The calyx is good. We recommend a generous watering, with good drainage. Night temperature 52 to 54 degrees suits it best.

Price $\$ 3.00$ per dozen, $\$ 15.00$ per 100 .

\section{New Carnation Sangamo.}

\section{COLOR} STEM

Brilliant, glistening pink, brighter than Winona.

Perfect, what we consider ideal; extra long, strong and stiff. Giving blooms on 16-inch stems in October, and increases to 30 to 36 inches. At no time of the year does the stem show any weakness, always holding the flower gracefully erect.

\section{PRODUCTIVENESS}

Exceedingly prolific, as new growth starts before the flower is taken, and grows rapidly, producing a fine bloom in remarkably short time. It is one of the very best commercial varieties on the market and will hold its own on the exhibition table, receiving high score and medals wherever shown.

\section{HABIT}

Strong, healthy and clean, with upright growth, making breaks easily from the base of the plant. The leaves are long and hard, not subject to stem rot or other disease, lifts easily from the field, and establishes itself readily. Night temperature 48 to 50 degrees suits it the best, although it does well if grown with other varieties at a higher temperature. Propagates easily.

Price 25c each, $\$ 3.00$ per dozen, $\$ 15.00$ per 100 . 


\section{New Carnation Conquest.}

\section{COLOR}

Light pink, overlaid almost to the edge with deep rose pink. One of the most striking and beautiful carnations. Does not fade, but rather improves with strong light.

HABIT

Lifts easily and establishes itself in the benches without any trouble, making a quick growth, and coming into crop early. Night temperature 50 to 52 degrees is the best, although it can be grown in the same house with other varieties with a higher or lower temperature.

Price 25c each, $\$ 3.00$ per dozen, $\$ 15.00$ per 100 .

\section{Varieties of 1908.}

Wanoka, Ruby, Apple Blossom, Pink Delight, May Day, Georgia, Mrs. J. C. Vaughan, O. P. Bassett, Bay State, Gov. Dineen.

Price 12c each, $\$ 1.25$ per dozen, $\$ 10.00$ per 100 . 21/2-inch pots, $2 c$ extra.

\section{Standard Kinds.}

Beacon, Brittania, Afterglow, Enchantress, Rose Pink Enchantress, White Enchantress, Mrs. Patten, Robt. Craig, Lloyd Winsor, Winona, Variegated Lawson. Rooted cuttings: Price 60c per dozen, $\$ 4.00$ per 100 . 21/4-in pot plants: $\$ 1.00$ per dozen, $\$ 7.00$ per 100 .

\section{Wells's New Early Flowering Single Chrysanthemums.}

I am now in a position to supply seeds of this sterling novelty. Nothing easier to grow. Sow in small pots in a green house if you have one, or in the open ground as soon as it can be worked in the spring, and pick off as soon as the seedlings are large enough to handle.

Plant out 18 inches apart in May, and you will have a profusion of bloom all the fall.

Hundreds of plants can be raised from a packet of seeds, and every one will be a different variety. If lifted in the fall and potted, these plants will flower for weeks, equally well in the green house or the house window.

Singe chrysanthemums are the craze at the present time, and from a single packet of seed you can get sorts equal to the best named varieties. Trial packets at $25 \mathrm{c}$ and $\$ 1.00$ per packet.

\section{Wells's Grand Diploma Pentstemons.}

An entirely new race of pentstemons that gives the most glorious combinations of colors in scarlet, crimson, pink and white. The plants grow $2 \mathrm{I} / 2$ feet high and the flower spike is 18 inches long; the individual flowers being two inches across. No one who has not seen these pentstemons can form any idea of the brilliant display a bed of these plants presents. They will be hardy in the southern states, and being perennials will grow and increase in size and beauty every year. No trouble to grow. Treat the seedlings as you would asters and plant out a foot apart.

You will get more satisfaction out of a packet of these seeds than any other flower you ever grew. A 25c packet contains about 100 seeds. Packets 25c and $\$ 1.00$ each. 


\section{Roses, Newer Varieties.}

WHITE KILLARNEY. This is a pure white sport from the Killarney now so largely grown. It has exactly the same heavy producing qualities that have made that parent one of the most profitable roses to handle. Growth is identical in every respect and the color of the flower is the only variation. Price for March delivery, $2 \mathrm{~T} / 2$-inch pots, own root, $15 \mathrm{c}$ per plant, $\$ 12.00$ per 100; grafted stock $5 \mathrm{c}$ extra.

MY MARYLAND. A lovely pink rose that seems destined to make a place for itself. It is a wonderful producer and the color a clear, rosy pink, leaves nothing to be desired. Bud is long and pointed, and growth free and healthy. Well worth a trial by anyone.

RHEA REID. Makes a big bush with me, and should be planted on the center bench. Color is rose cerise in hot weather, shading to Richmond red in winter. No mildew or black spots. The very finest outdoor rose we have.

MRS. JARDINE. This rose is making good everywhere; color, bright rosy pink shading to salmon. A free kind grower, no mildew or black spot, and every shoot produces a flower.

QUEEN BEATRICE. Color of Bridesmaid. Free and vigorous grower. It is claimed that this variety will produce three times as many flowers as Bridesmaid. It is highly recommended by Washington florists. Price, own root, $2 \frac{1}{4}$-inch, $10 \mathrm{c}$ per plant, $\$ 8.00$ per 100 .

\section{Standard Varieties.}

AMERICAN BEAUTY. My stock of this rose is not surpassed in this country and I can always quote in any quantity $2 \mathrm{I} / 2$-inch pots, $\$ 1.50$ per dozen, $\$ 8.00$ per 100. Larger sizes up to 4 inches, prices on application.

BRIDESMAID. The most largely grown pink.

BRIDE. The most largely grown white.

GOLDEN GATE. Creamy white flushed pink, very free.

IVORY. White sport of Golden Gate.

KAISERIN. Ivory white, largely grown for summer flowering.

KILLARNEY. Bright pink, beautiful in bud.

M. A. CHATENAY. Bright pink, enormous producer.

PERLES. A favorite old yellow rose.

RICHMOND. The best forcing red rose.

SUNRISE. Scarlet and yellow, sport of Perle.

SUNSET. Golden amber, sport of Perle.

Price, $2 \mathrm{~T} / 2$-inch plants, $\$ 1.00$ per dozen, $\$ 6.00$ per 100 . Special prices 4-inch stock, June delivery. Grafted plants of all the popular kinds, $21 / 2$-inch, $\$ 15.00$ per $100, \$ 120.00$ per 1,000 . Larger sizes on application.

\section{New Alternanthera Jewel.}

A novelty of sterling merit, indispensible for bedding where foliage plants are used. It surpasses all other forms of alternanthera in brilliancy of color, freedom of growth, habit, etc. It is of the latifolia type but not the least straggly or coarse, but on the contrary compact and uniform. It makes an excellent border plant and is unequalled for massing. The young growth is of a beautiful bronzy orange color veined with red, changing to a rosy-carmine and brilliant cerise.

Price, 21/4-inch pots, $\$ 2.00$ per dozen, $\$ 15.00$ per 100 . 


\section{Miscellaneous Plants.}

\section{Ferns.}

Mixed ferns for fern dishes, $2 \frac{1}{4}$-inch pots, $\$ 5.00$ per 100 , in all the best varieties, Crytomium Falcatum, Pteris Mayii, P. Cretica, P. Albo, Lineata, P. Adiantoides, etc.

\section{Gardenias.}

I will be in a position to quote this popular plant spring and early summer delivery at $\$ 20.00$ per $100,21 / 2$-inch pots; $\$ 30.00$ per 100,3 or 4 -inch pots.

\section{Geraniums.}

We can quote in any quantity on some 200 varieties; all the best for bedding or winter flowering, from $\$ 5.00$ per 100 up. Special list issued in spring.

\section{HELIOTROPE.}

LEMOINES. Giant blue. $\$ 1.00$ per dozen, $\$ 6.00$ per 100 .

LEMON VERBENA. $\$ 1.00$ per dozen, $\$ 6.00$ per 100.

$$
\text { LOBELIA. }
$$

CRYSTAL PALACE GEM. Dwarf blue.

KATHERINE MALLARD. Double blue.

$75 \mathrm{c}$ per dozen, $\$ 5.00$ per 100 .

\section{Lantanas.}

A. CLAVEAN. Primrose pink and sulphur.

CISERON. Madder red with golden center.

DELICATISSIMA or WEEPING. Lilac lavender; one of the finest basket plants that we have.

E. BAYARD. Bright orange red and yellow.

CRAGI. Bright orange, fading to rich crimson.

F. GIVARDEAU. Clear orange yellow.

FRANCINE. Sulphur yellow and deep pink. low flowers.

HARKETT PERFECTION. Variegated foliage; light pink and yel-

IOLANDA. Fine, large, pure white; semi-dwarf.

JUAN d'OR. Light sulphur, fading to deep rose pink.

LEO DEX. Opens orange scarlet, changes to dark crimson; robust grower; extra fine.

PROTEE. Old rose and golden yellow.

RADIATION. A grand combination of color; brilliant red shading.

SALMONEA. Semi-dwarf; an exquisite shade of bright salmon pink. $\$ 2.00$ per dozen, $\$ 10.00$ per 100 .

Price $\$ 1.00$ per dozen, $\$ 5.00$ per 100 , except where noted.

\section{Moonvines.}

NOCTIFLORA. The standard white Moonvine.

LEARI (Blue Dawn Flower). Generally known as the blue Moonflower. Price $\$ 1.00$ per dozen, $\$ 5.00$ per 100 .

\section{Panicum Variegated.}

PRETTY, VARIEGATED GRASS. For baskets, vases, etc.

Price $\$ 1.00$ per dozen, $\$ 5.00$ per 100 . 


\section{Salvia.}

BONFIRE. Dwarf, scarlet.

SPLENDENS. Tall, scarlet.

ZURICH. Dwarf, scarlet.

Price $\$ 1.00$ per dozen, $\$ 5.00$ per 100 .

\section{Senecio Scandens.}

(Parlor Ivy)

INDISPENSABLE CLIMBER. For vases, baskets or boxes.

Price 75c per dozen, $\$ 5.00$ per 100 .

\section{Tradescantia.}

DARK VARIEGATED. Price 75c per dozen, \$5.00 per 100.

\section{Verbena.}

LARGE FLOWERING VARIETIES. In separate colors.

Price 75 c per dozen, $\$ 5.00$ per 100 .

LARGE FLOWERING. Mixed.

Price 75c. per dozen, $\$ 5.00$ per 100 .

\section{Grasses.}

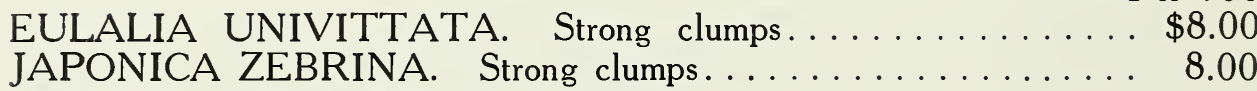

STRATIS. Strong clumps ....................... 8.00

ERIANTHUS RAVENNAE. Strong clumps........... 8.00

\section{Amaryllis Hippeastrum.}

I have a quantity of seedlings saved from hand fertilized flowers of the finest strain of Veitch's hybrids. These are certain to produce many beautiful varieties and a batch of these in flower will produce a noble effect in any conservatory. I offer two-year-old seedlings, dormant bulbs, at $\$ 3.00$ per dozen, $\$ 20.00$ per 100 .

\section{Sweet Peas.}

Sweet peas for greenhouse culture in winter. By arrangement with Ant. C. Zvolaneck, the noted sweet pea expert, I am enabled to offer in season seed all of his standard varieties and novelties. For filling a house after chrysanthemums nothing is better or more useful than these peas. Send for circular giving complete list of varieties.

\section{How to Grow Chrysanthemums.}

\section{By A. HERRINGTON}

The most practical work ever written on this subject. Post paid on receipt of price, $50 \mathrm{c}$.

Contains chapters on every branch of the industry, and I can highly recommend it to everyone who needs a little information regarding feeding, taking the buds, or any other subject connected with the chrysanthemum. 


\section{HARDY POMPONS.}

\section{New Varieties. \\ 1909 Introduction.}

BRADSHAW. Silver pink; large, full flowers.

BILLY PRIMROSE. Small flowers: violet red; long stems.

BARNEY. Golden bronze; anemone.

BALTIMORE. Violet red; large single, quilled petals.

BABY MARGARET. Said to be a pure white sport of Baby; a very beautiful thing.

CUMBERLAND. Long stems; large flowers; pure yellow.

EXCELSIOR. Large flowers; bright orange yellow; long stems.

EXCELLENCE. Anemone; tall grown; pure white.

ELKTON. Light pink; full large flowers.

ELIANOR. Small flowers; dwarf; fimbriated; petals white.

GERMANIA. Large flowers; straw white; long stems.

HERO. Clear pink; large flowering.

JERSEY. Large flowering; pure white.

KENNITH. Pure white; large flowers.

LORLEY. Large full flowers; yellow, tinged pink.

LITTLE GEORGE. Small-flowered; violet red.

MYERS' PERFECTION. Anemone; fine, pure, white; tall grower.

PRINCE DANILO. Pure white anemone.

REV. W. M. HOFFMAN. Bronze, tipped yellow; large-flowering.

SILVER QUEEN. Silver pink; largeflowering.

SYLVIA. Large-flowering, scarlet bronze; tall grower.

TRIOMPHE d'OR. Rich golden yellow.

URITH. Large flowers, broad petals; bronze, tipped yellow.

VIOLA. Rich violet red; small flowers.

WINDLASS. Rich orange, yellow; large flowers.

YELLOW GEM. Large, full flowers; pure yellow.

Price $\$ 2.00$ per dozen, $\$ 10.00$ per 100 .

\section{Large-Flowering or Aster Varieties.}

ALLENTOWN. Golden bronze; for cut flowers.

ASHBURY. Sulphur white; for cut flowers.

AUSTIN. Lilac rose, cut petals.

BERTHA. Large white open center.
BOHEMIA. Fine pure white; for cut flowers.

BOSTON. Golden bronze.

DINIZULU. Light rose.

DUNDEE. Dark red.

ELDORADO. Bright golden, open center.

ELOISE. White open center.

FINDON. Violet rose.

FLOSSIE. Silver pink.

FRED J. Red orange; for cut flowers.

GLADYS. Flushed pearl.

GLOBE d'OR. Dwarf; clean yellow.

GLOIRE DE FRANCE. Silver pink;

long stems.

GERTRUDE. Pure white; open center.

HAMLET. Violet red.

HESTER. Pearl white, shaded flesh.

HIJOS. Beautiful primrose pink; for cut flowers.

IDA. Bright golden yellow; early.

IRENE. Pure white, shaded flesh.

JERRY. Rose lilac.

JOPPA. Violet crimson; for cut flowers.

JULIA LAGRAVERE. Crimson maroon; for cut flowers.

KING HENRY. Straw white; long stems.

KING PHILIP. Rich rose pink.

LADY NAYLOR. White.

LOUISA. Large white; long stems.

MISS JULIA. Orange red, turning to yellow.

MRS. PORTER. Bright bronze; for cut flowers.

MRS. SNYDER. Pure golden yellow.

PENELOPE. Large white; tall.

PATTERSON. Old gold, dark shading.

PETO. Rich bronze.

PRINCE OF WALES. Best pure white; for cut flowers.

QUEEN OF BUL. Violet rose.

QUEEN OF WHITE. Fine creamy white; long stems.

SALEM. Silver rose; long quilled.

SIR MICHAEL. Lemon yellow, open center; for cut flowers.

STRATAGEM. Dark red orange.

ST. ILLORIA. Silver rose; quilled petals; for cut flowers.

ST. ALMO. Splendid white; for cut flowers.

THE CZAR. Golden bronze, tipped red.

THE HUB. Fine, white open center.

For cut flowers.

TIVOLA. Fine rose.

WILLIE. Lilac and white.

$\$ 1.00$ per dozen, $\$ 5.00$ per 100 .

\section{Small-Flowered or Button Varieties.}

AGALIA. Light orange, shaded pink; for cut flowers.

ALICE CARY. Pure yellow. 
Small-Flowered or Button Varieties -Continued

ANNA MARY. Creamy white, shaded pink.

BABY. Smallest golden yellow.

BROWN BESSIE. Dark bronze.

CERISE QUEEN. Cerise pink; for cut flowers.

DAWN. Daybreak pink.

EAGLE d'OR. Chrome yellow.

ELEGANTA. Deep rose, shaded white. ERMINE. Bright orange scarlet.

FASHION. Maize yellow; for cut flowers.

FRED PEELE. Lilac red.

GOLDEN PHEASANT. Deep orange yellow.

HENRIETTA. Bronze, yellow edge.

JAMES BOONE. Pure white.

JEANETTA. Silver bronze and rose.

LITTLE PET. Rich violet red; for cut flowers.

LYNDHURST. Deep scarlet bronze.

NELLIE BLY. Blush pink.

NELLIE RAINSFORD. Very dwarf; light pink.

RHODA. Pink, shaded white.

RUFUS. Crimson maroon.

SUNSHINE. Bright golden yellow; for cut flowers.

TENNYSON. Pure yellow; for cut flowers.

\section{Anemone Varieties.}

EARL. Pearl white, silver rose center; dwarf.

FURNESSIA. Silver white; for cut flowers.

LADY OLIVIA. Beautiful white.

GRACIE. White, full center; for cut flowers.

MATILDA. White.

OBAN. Silver pink, full anemone center; for cut flowers.

\section{Single Varieties.}

AARON. Bronze scarlet.

NORTHUMBERLAND. Bright scarlet, yellow disc.

ROSY MORN. Silver pink.

PROVIDENCE. Early white.

SIR WALTER RALEIGH. Light bronze.

WALLIS. Pure yellow.

Price $\$ 1.00$ per dozen, $\$ 5.00$ per 100 .

\section{Miscellaneous Plants}

A general assortment of plants for all purposes. Decorative, bedding or greenhouse stock.

All plants priced, when sizes are not mentioned, are from 2 -inch pots. Not less than five of any one variety sold.

\section{Acalypha.}

MACAFEEANA. A very handsome ornamental foliage and bedding plant; cardinal, red and chocolate variegated.

Price $\$ 1.00$ per dozen, $\$ 5.00$ per 100 .

\section{Ageratum.}

100.

INIMITABLE. Giant blue, $\$ 3.00$ per

DWARF WHITE.

PRINCESS PAULINE. Sky blue, white center.

STELLA GURNEY. Dwarf, deep purple blue.

Price 75 c per dozen, $\$ 5.00$ per 100 .

\section{Alternanthera.}

AMOENA ROSEA. Rose and carmine.

AUREA NANA. Yellow, compact.

BRILLIANTISSIMUS. Rich carmine.

SEYBOLDI. Broad leaf; yellow.

VERSICOLOR. Crimson, chocolate and green.

PROSPECT PARK BEDDER. Dark chocolate red. red.

CARROLL PARK BEDDER. Dwarf, Price $\$ 4.00$ per 100 .

\section{Alyssum, Sweet.}

DWARF DOUBLE. Best for pot plants and pans.

GIANT DOUBLE. Splendid for cutting.

Price 75c per dozen, $\$ 4.00$ per 100 .

\section{Begonia.}

SEMPERFLORENS. White and rose.

GRACILIS. White and rose.

VERNON. White and pink.

Price $75 \mathrm{c}$ per dozen, $\$ 5.00$ per 100 .

\section{Cannas.}

Strong plants from 3 -inch pots

JEAN TISSOT. An intense brilliant vermilion, with bright orange shading. It is one of the brightest of the large-flowered Cannas, massive green foliage of uniform growth, about 5 feet high.

Price $\$ 1.50$ per dozen, $\$ 7.50$ per 100 .

PRESIDENT MYERS. Rich cherry carmine, immense trusses of large flowers; bronzy foliage; about 4 feet.

Price $\$ 1.50$ per dozen, $\$ 7.50$ per 100 .

LOUISIANA. A strong vigorous growing variety, producing a dense mass of glossy green foliage, large vivid scarlet flowers often measuring 7 inches across. About 7 feet.

Price $\$ 1.50$ per dozen, $\$ 7.50$ per 100 .

PENNSYLVANIA. Produces very large flowers of a bright vermilion scarlet overlaid with an orange sheen; remarkably free flowering.

Price $\$ 1.50$ per dozen, $\$ 7.50$ per 100 . 


\section{Cannas-Continued}

BUTTERCUP. Deep buttercup yellow, almost pure; the finest yellow; foliage deep green. About 3 feet.

Price $\$ 1.50$ per dozen, $\$ 7.50$ per 100 .

KING HUMBERT. In this we have the highest type of orange-scarlet flowers combined with the finest type of bronze foliage.

Price $\$ 2.00$ per dozen, $\$ 12.00$ per 100 .

RICHARD WALLACE. Canary yellow, large flowers, freely produced. Four and one-half feet.

Price $\$ 1.50$ per dozen, $\$ 7.50$ per 100 .

\section{Standard Varieties.}

J. D. EISELE. Bright vermilion scarlet. EGANDALE. Four feet. Bronze foliage, currant-red flowers.

ALPHONSE BOUVIER. Crimson; 6 feet high.

MME. CROZY. Bright scarlet, golden border.

FLORENCE VAUGHAN. Five feet. Green foliage, rich golden yellow, dotted red.

Price $\$ 1.00$ per dozen, $\$ 6.00$ per 100 .

\section{Cineraria.}

MARITIMA CANDIDISSIMA. Silver foliage.

Price $\$ 1.00$ per dozen, $\$ 5.00$ per 100 .

\section{Centaurea.} iage.

GYMNOCARPA. Fine cut silver fol-

Price $\$ 1.00$ per dozen, $\$ 5.00$ per 100 .

\section{Coleus.}

GOLDEN BEDDER. The standard yellow border.

VERSCHAFFELTII. The standard crimson bedder and other good bedding sorts. QUEEN VICTORIA, ELDORADO, FIRE BRAND, and other standard sorts.

Price 75c per dozen, $\$ 4.00$ per 100 .

\section{Dahlias.}

\section{Cactus-Flowering Varieties.}

Price $\$ 1.25$ per dozen, $\$ 10.00$ per 100 .

ALEXANDER IMMER. Rich velvety maroon.

AEGIR. Rich bright crimson scarlet.

BLANCHE KEITH. Rich yellow; long petals.

BRITANNIA. Deep salmon flesh.

BRUNHILDE. Rich plum; long petals.

COMET. Silver rose, speckled and striped crimson.

COUNTRY GIRL. Deep golden yellow, bronze and red.
COUNTESS OF LONSDALE. Rich salmon.

CRIMSON BEAUTY. Shining crimson. DUCHESS OF HAMILTON. Sulphur white, shaded pink.

DOROTHY VERNON. Crushed strawberry.

FLORA. Large pure white.

FLORADORA. Dark velvety c crimson. GABRIEL. Soft crimson, tipped white.

GENERAL BULLER. Dark velvety maroon, tipped white.

GOV. WARFIELD. Pure white.

GRACIE. Salmon red with a sheen of purple.

HARBOR LIGHT. Vivid orange red. HOBBIE'S YELLOW. Bright golden yellow.

H. SHOESMITH. Brilliant orange crimson.

INNOCENCE. Lemon yellow, margined white.

INTERNATIONAL. Bright orange scarlet.

IRENE. Deep purple plum.

J. H. JACKSON. Brilliant, very dark crimson maroon.

JULIET. Rosy pink, shading to white center.

KONIGEN WILHELMINA. Crimson, shaded maroon.

KRIEMHILDE. Brilliant pink, shading to creamy white center.

LORD OF THE MANOR. Bright crimson.

LIBERTY. Dark crimson maroon.

MARJORIE CASELTON. Rose pink, white center.

MASTER CARL. Large clear orange salmon.

MISS D. OLIVER. Primrose yellow.

MRS. CLINTON. Deep amber, shading to rosy scarlet.

MINNIE WEST. Canary yellow center, white tips.

MORNING GLOW. Deep primrose.

MRS. F. GRIMSTED. Deep rich crimson.

MRS. CHAS. SCOTT. Old gold, shad. ed apricot.

MRS. G. STEVENSON. Sparkling bright yellow.

MRS. H. J. JONES. Bright scarlet.

NELSON. Rich crimson, shaded bright magenta.

PRETORIA. Dazzling vermilion.

PROGENITOR. Rich carmine.

RADIUM. Orange rose.

REV. D. R. WILLIAMSON. Large bright maroon.

RELIABLE. Madder carmine.

ROYAL SCARLET. Bright scarlet.

SILVER WINGS. Silvery white.

STANDARD BEARER. Rich fiery scarlet.

STRAHLEIN KRONE. Cardinal red. 


\section{Dahlias-Continued.}

THE PILOT. Bright terra cotta, yellow center.

THURINGIA. Light fiery red.

THOMAS PARKIN. Bright terra cotta.

VOLKER. Clear lemon yellow.

WINSOME. Pure white.

YELLOW GEM. Pure light yellow.

BARON SCHROEDER. Rich glowing purple.

BLACK BEAUTY. Rich black velvety maroon.

CLIFFORD W. BRUTON. Canary yellow.

COUNTESS OF PEMBROKE. Soft rosy lake.

ELOISE. Blush pink, shading to white center.

EUREKA. Deep rose.

FRANK L. BASSETT. Bright rosy purple.

FIRE RAIN. Rich cardinal red.

GRAND DUKE ALEXIS. Ivory white. HENRY PATRICK. Large, pure white. JEAN CHARMANT. Pink, lilac at edges.

JOHN ELITCH. Rich cardinal red.

JUMBO. Rich glowing crimson.

MISS MAY LOMAS. Waxy white and lavender.

MME. VAN DEN DAEL. Silver pink. MME. A. LUMIER. Pale white.

MRS. HARTONG. Rich golden bronze. MRS. WINTERS. Pure white.

MRS. ROOSEVELT. Delicate silvery rose.

ORANGE KING. Rich glowing orange. PENDANT. Bright crimson maroon. PRINCESS VICTORIA LOUISE.

Deep rose pink. SOUV. DE GUSTAVE DUZON. Large orange red.

SYLVIA. Rich pink.

WM. AGNEW. Vivid glowing scarlet. YELLOW LE COLOSSE. Brightest yellow.

Price \$1.25 per dozen, \$10.00 per 100 .

\section{Show Varieties.}

A. D. LIVONI. Rich sea-shell pink.

ARABELLA. Pale primrose.

BLACK DIAMOND. Purple garnet, shaded black.

BON TON. Deep rich garnet.

CAMELLIAFLORA. Splendid dwarf white.

CLIENT. Deep velvety crimson.

CUBAN GIANT. Dark crimson.

CHAS. LANIER. Yellow amber, shaded buff.

DAVID JOHNSON. Salmon and rose.

ELECTRIC. Soft rosy magenta.

ETHEL. Pure yellow, tipped white.

EMILY. Varying from rosy lavender to white.
FRANK SMITH. Dark rich maroon, tipped white.

GETTYSBURG. Rich pure scarlet.

GLORIE DE LYONS. Fine, large, pure white.

HERO. Deep crimson maroon.

KEYSTONE. Pink striped and blotched crimson.

MAGNIFICENT. Pure yellow.

MARGUERITE BRUANT. Pure white.

M. D. HALLOCK. Pure yellow; early free bloomer.

MME. ZELLER. Rich orange and pink.

MRS. DEXTER. Rich salmon.

MRS. LANGTRY. Peach pink.

ORLANDO. Buff salmon.

PINK DANDY. Deep pure pink; long stiff stems.

PSYCHE. Primrose, tinted pink; dwarf. QUEEN OF YELLOWS. Pure yellow. QUEEN VICTORIA. Pure golden yellow.

RUBY QUEEN. Clear ruby red.

SNOW. Pure white.

SOUV. DE MME. MOREAU. Deep, rich pink.

STANLEY. Bright golden yellow.

STRIPED BANNER. Crimson, striped white.

WHITE SWAN. Fine pure white.

TRIOMPHE DE SOLFERINO. Large, deep solferino.

ZEBRA. Pearl and white blotched.

Price $\$ 1.25$ per dozen, $\$ 10.00$ per 100 .

\section{Pompon Varieties.}

ALLIE MOUREY. Pinkish white.

CRIMSON QUEEN. Deep crimson, shaded purple.

ELEGANTA. Deep soft pink, edged deeper pink.

INDIAN CHIEF. Crimson.

LITTLE BEAUTY. Delicate shrimp pink.

LITTLE HELEN. Pure white.

LITTLE MAY. Bright lemon yellow.

RAPHEAL. Deep rich maroon.

ROSALIE. Yellow, edged crimson.

SNOWCLAD. White.

Price \$1.25 per dozen, \$10.00 per 100 .

\section{Single Varieties}

AMI BARILLET. Scarlet crimson.

ALBA SUPERBA. Large pure white.

FASHION. Crimson maroon.

LORD ROSEBERY. Bright orange.

NELLIE HUGHES. Deep rosy lake.

ST. GEORGE. Large pure yellow.

WILD FIRE. Very brilliant scarlet.

STRIKING. Dark rich maroon, tipped white.

Price $\$ 1.25$ per dozen, $\$ 10.00$ per 100 . 


\section{$\therefore$ \\ TERMS OF SALE}

Prices quoted are for $2{ }_{4}^{1}$ inch pot stock delivered in strict rotation and shipped out in the new year as ready. My stock is now shipped to all quarters of the globe and long distance shipments are specially hardened before shipment, practically guaranteeing safe delivery. Any stock sent out by me may be returned at my expense if not found entirely satisfactory. My stock is all flowered under glass so that the plants can be carefully rogued and the possibilities of stock being mixed is reduced to a minimum.

TERMS. Orders from unknown parties must be accompanied by cash or satisfactory references. I allow $5 \%$ discount when cash accompanies order. Bills unpaid in 60 days subject to sight draft without further notice. Orders from South America or Australia must always be accompanied by cash, unless otherwise agreed on.

European customers will kindly note that orders for Great Britain or the Continent will be filled by my English Agents, W. Wells \& Co., Merstham, Surrey

EXPRESSAGE. All plants are shipped by express unless otherwise ordered, and go at the special plant rate which is $20 \%$ less than regular rates. I will include enough extras in any order to offset the cost of expressage. In the absence of definite shipping instructions I always bill by quickest and cheapest route. 